HIAS-E-51

\title{
Geopolitics and Asia's Little Divergence: State Building in China and Japan After 1850
}

\author{
Mark Koyama \\ Department of Economics, George Mason University \\ Chiaki Moriguchi \\ The Institute of Economic Research, Hitotsubashi University \\ Tuan-Hwee Sng \\ Department of Economics, National University of Singapore July 2017
}

2-1, Naka, Kunitachi, Tokyo 186-8601, Japan

tel:+81 425808604 http://hias.ad.hit-u.ac.jp/

HIAS discussion papers can be downloaded without charge from:

http://hdl.handle.net/10086/27202

https://ideas.repec.org/s/hit/hiasdp.html

All rights reserved. 


\title{
Geopolitics and Asia's Little Divergence: State Building in China and Japan After 1850
}

\author{
Mark Koyama, Chiaki Moriguchi, Tuan-Hwee Sng*
}

July 2017

\begin{abstract}
We provide a new framework to account for the diverging paths of political development in China and Japan during the late nineteenth century. The arrival of Western powers not only brought opportunities to adopt new technologies, but also fundamentally threatened the sovereignty of both countries. These threats and opportunities produce an unambiguous impetus toward centralization and modernization for small states, but place conflicting demands on larger states. We use our theory to study why China, which had been centralized for much of its history, experienced gradual disintegration upon the Western arrival, and how Japan rapidly unified and modernized.
\end{abstract}

Keywords: China; Japan; Geopolitics; State Capacity; Political Fragmentation; Political Centralization; Economic Modernization

${ }^{*}$ Mark Koyama, Department of Economics, George Mason University. Email: mkoyama2@gmu.edu. Chiaki Moriguchi, Institute of Economic Research, Hitotsubashi University. Email: chiaki@ier.hit-u.ac.jp. Tuan-Hwee Sng, Department of Economics, National University of Singapore. Email: tsng@nus.edu.sg. We are grateful for comments from Tyler Cowen, Nathan Nunn, Jack Paine, Jean-Laurent Rosenthal, Noam Yuchtman, and participants at the 2015 World Economic History Congress in Kyoto, the Frontiers in Chinese Economic History Conference in Berkeley, the CUHK 6th Annual Conference on Chinese Economy, George Mason Economic History and Development Workshop, and the 2016 NBER Japan project meeting. Pei Zhi Chia provided valuable research support. We gratefully acknowledge financial support from Hitotsubashi University IER Joint Usage and Research Center Grant (FY2016) and Singapore Ministry of Education Academic Research Fund Tier 1 (FY2014-FRC3-002). 


\section{INTRODUCTION}

We investigate the process of state building and economic modernization through a comparative study from Asia: why did Japan successfully build a modern state in the late nineteenth century, while China did not? Both China and Japan came under increasing threat from the Western powers during the nineteenth century. This was a "critical juncture" for both economies, to use the terminology of Acemoglu and Robinson (2012). In response, Japan undertook a program of state building and modernization; in China, however, a more limited attempt to modernize the state proved unsuccessful and the power of the central state was weakened. This transformation set the stage for nearly a century of political turmoil in China, and the onset of sustained economic growth in Japan.

The divergence between China and Japan after 1850 poses a potential conundrum to the economic history and political economy scholarship. ${ }^{1}$ It is puzzling, first of all, from the perspective of the large literature that stresses the importance of external wars as engines of state building: both China and Japan were confronted with external threats in the second part of the nineteenth century, but only Japan embarked on a comprehensive program of modernization. Second, the dichotomous outcome we observe is at odds with what one might expect from a superficial assessment of the internal political histories of the two countries. China had a longer history of continuous statehood (Fukuyama, 2011) and the Qing state in 1800 was more centralized than was Tokugawa Japan. A third reason to revisit this particular case study is that the initial East Asian divergence in state building was not driven by internal conditions such as the pressures of industrialization as in variants of the modernization hypothesis (Lipset, 1963) or by the threat of democracy as modeled by Acemoglu and Robinson (2001), but was rather a response to radical changes in the external environment brought forth by the rise of the West.

To address this puzzle we develop a unified framework to study how states manage the twin goals of defense and development-when these goals are complementary and when are they in conflict? To illustrate the utility of the framework, we use it to account for China's and Japan's diverging paths of political development and for the difference in their attitudes toward broad-based reforms in the second half of the nineteenth century.

Our main contribution is to the literature on the role of institutions in long-run growth and economic history (e.g., North, 1981, 1990; North et al., 2009; Acemoglu et al., 2005). In recent years, increasing attention has been paid to the importance of states being both effective in providing basic public goods and strong enough to prevent rent-seeking interests from vetoing

\footnotetext{
${ }^{1}$ For conciseness, we use "1850" to represent the time point at which the break between premodern and modern eras occurred in China and Japan. Therefore, post-1850 represents the period after the First Opium War (1839-42) in China and the period after the Black Ship Incident (1853) in Japan.
} 
pro-growth policies (North et al., 2009; Besley and Persson, 2011; Hoffman, 2015a). ${ }^{2}$ We study the problem of state building in the context of a hostile external environment to offer a novel understanding of why external threats could encourage the rise of a strong and effective state in some instances but not in others.

The second novel feature of our analysis is that we highlight the spatial dimension of state building. The literature on state capacity usually treats state building as a spatially uniform process: state capacity, once built, applies uniformly throughout the country. ${ }^{3}$ But clearly, the state is not omnipresent - by default, it will be more effective in some locations (e.g., in and around the capital city) than in others (e.g., in peripheral regions). This makes maintaining effective control a more complicated task in a large state than in a small one, which, in turn, has implications on their respective abilities and willingness to pursue socioeconomic reforms.

Thirdly, the seminal contributions in this literature have thus far focused on Western Europe (e.g., North and Weingast, 1989; North et al., 2009; Dincecco, 2009; Dincecco and Katz, 2014). It is only recently that scholars have considered the process of state formation and modernization in other parts of the world such as Latin America (Arias, 2013) or East Asia (Slater, 2010; Vu, 2010; He, 2013; Paik and Vechbanyongratana, 2017). While there is an extensive literature on the developmental state in East Asia (e.g., Haggard et al., 1997; Doner et al., 2005), it focuses largely on the post-1945 experience instead of on the original point of divergence in state building that took place in the nineteenth century as this paper does.

The conventional wisdom emphasizes Meiji Japan's eagerness and commitment to emulate the West in implementing broad-based reforms and the lack thereof in China as a key ingredient of their post-1850 divergence (Fairbank and Reischauer, 1989; Paine, 2003; Ma, 2004). ${ }^{4}$ Less well known is the fact that like China, Japan, too, experienced considerable popular resistance toward reform, but it overcame the resistance through resolute state policy (Aoki, 1971; Tanaka, 2004). Hence, we argue that the observed differences in reform attitude between the two countries were not exogenously formed. Instead, they were, at least in part, shaped by the interaction of external challenges and domestic constraints in the two economies. In the spirit of the scholarship that highlights the role of war in state building (Tilly, 1990; Hoffman, 2015b; Gennaioli and Voth, 2015) and work that emphasizes how the size of a polity determines its economic policies (Alesina and Spolaore, 2003; Rosenthal and Wong, 2011), we build a model in which the respective needs

\footnotetext{
${ }^{2}$ Recent surveys are provided by Dincecco (2015) and Johnson and Koyama (2017).

${ }^{3}$ The only exception that we are aware of is Acemoglu et al. (2015), who study subnational variations in state capacity in Colombia. Michalopoulos and Papaioannou (2014) provide evidence that in many African countries the reach of central government does not extend into the periphery where ethnic level institutions have a greater impact on developmental outcomes than national institutions. The implications of polity size for fiscal capacity in Qing China are also considered by Sng (2014) and Ma and Rubin (2017).

${ }^{4}$ As Mokyr $(1990,231)$ put it, "Japan adopted European technology rapidly lock, stock, and barrel, while China tried for decades to import European arms while preserving its old social and economic institutions".
} 
to deal with external threats and provide domestic order interact to influence the incentives and actions of policymakers. We use the model to explain (1) the political status quo in China and Japan (centralization in China and decentralization in Japan) before the mid-nineteenth century; (2) why China moved toward decentralization while Japan became politically centralized upon the arrival of Western powers; and (3) why despite considerable societal resistance to reform in both countries, ruling elites in Japan pushed forward with comprehensive reform while the Chinese leadership displayed ambivalence and was reluctant to change. While we focus on the political economy dimensions of the decision to modernize or not, our analysis complements other recent work that emphasizes the cultural and ideological determinants of the success of Meiji Japan and comparative failure of late Qing China (see, for instance, Iyigun and Rubin, 2017).

Our analysis draws attention to the relative size of China and Japan in shaping their institutional responses to the threats that they faced in the late nineteenth century. We build on the Hotelling-style linear city model employed in Ko, Koyama, and Sng (2014) to study how geopolitics generate systematic tendencies toward state centralization or state decentralization. It predicts that a singular external threat, such as the historical threat posed by the steppe nomads along China's northern frontier, generates a systematic tendency toward centralization. However, powerful threats from multiple fronts have a differential impact on states of different sizes. The weakest states would collapse while other small states would seek centralization (resource pooling) and reform (resource augmentation) to cope with the threats. But for large states that are handicapped more by organizational diseconomies of scale than by resource constraint, the threats can lead to the decentralization of political authority and a weaker desire for reform.

The point we emphasize is that to the rest of the world, the rise of the West brought not only opportunities to adopt radically new technologies and practices (such as steam engines, railroads, and public education), but also powerful threats to national sovereignty. These geopolitical threats endangered the survival of the smallest states with the least resources most, while large states faced great costs of implementing reforms to adopt the new technologies due to organizational complexities. By comparison, states in the middle of the spectrum, like Japan, were most incentivized to embark on a program of centralization and modernization.

For China, traditionally a land-based continental empire with a stronger military-political establishment in the north than in the south, the rise of European naval power demanded urgent actions to bolster coastal defense and strengthening the presence of the state in South China, at a time when it was facing renewed pressure along its Inner Asian land frontier from the Russians (Liu and Smith, 1980). The inefficiency of coordinating the twin responses from a single center on the one hand, and the central authority's unwillingness to concede too much autonomy to the 
provinces on the other contributed to the Qing dynasty's wavering between centralization and decentralization from the mid-nineteenth century through until the dynasty's collapse in 1912.

Our model further highlights that for a large state, the goals of defense and development are not congruent. To take full advantage of the new economic and technological possibilities, a large state like China needs to decentralize and allow provincial authorities to take the lead in implementing initiatives such as building schools and roads that serve local needs. However, decentralization may generate collective action problems in defense and diplomacy. Here again, the rise of the West meant that Chinese policymakers were confronted with conflicting objectives.

Dealing with the challenge of the West was not easy for Japan either. Like the leaders of Qing China, the political leadership in Japan reacted to the mid-nineteenth century crisis under huge uncertainty (Jansen, 2000; He, 2013). But as an island state, Japan's national and local objectives of security and reform were broadly complementary; the contradiction between political centralization and local state building did not exist. Hence, it took less time for the Japanese leaders to reach a consensus over what had to be done politically to confront the mid-nineteenth century crisis: the feudal system of the Tokugawa period had to be replaced by a centralized government so that Japan could pool its relatively limited resources to mount a coordinated response to the threat of Western imperialism.

Our analysis does not only shed light on the diverging developments in China and Japan. It also illuminates the loss of sovereignty to small East Asian states such as Korea, Sulu, and Vietnam during the same period and the demise of large empires including Tsarist Russia and Ottoman Turkey in the early twentieth century. To further derive generalizable insights from our framework, we also highlight the parallels between our cases and an earlier historical episode: the ninth-century unification of Anglo-Saxon England and fragmentation of the Carolingian empire.

The remainder of the paper is organized as follows. In Section 2, we first provide the historical background on nineteenth-century East Asia to derive the observations to be explained by our model, presented in Section 3. In Section 4, we discuss how our theory sheds light on the divergence between China and Japan after 1850. We then discuss the application of our framework on other episodes of state formation and fragmentation as well as potential limitations and extensions in Section 5. Section 6 concludes.

\section{The Puzzle: State Centralization And MOdERnization in EAST Asia}

Why did the emergence of geopolitical threats from the West in the second half of the nineteenth century have differential effects on state building in different parts of East Asia? The existing 


\section{Figure 1}

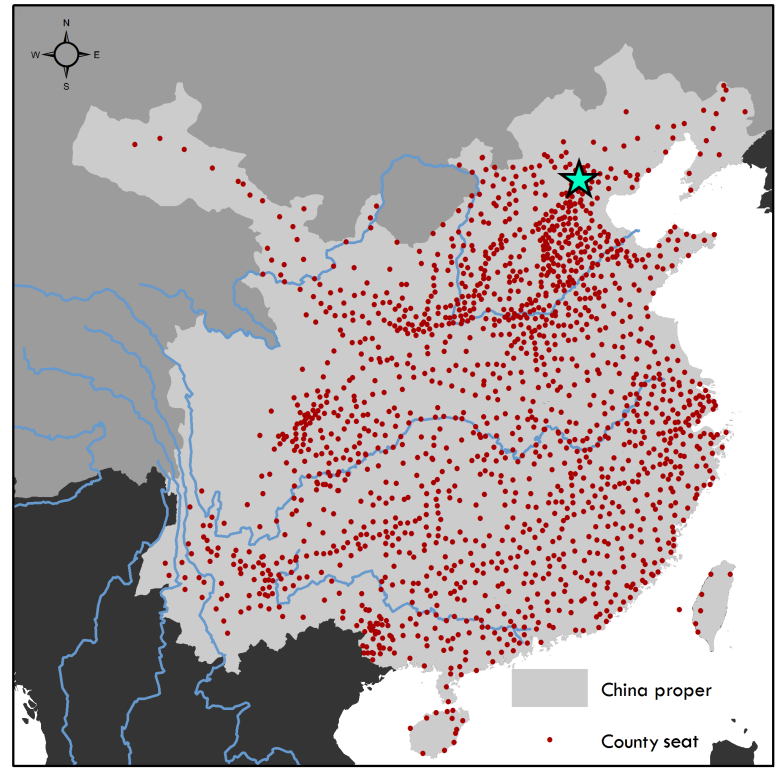

(a) Traditionally, the Chinese state had a stronger presence in the north than in the south as reflected in the distribution of the counties. Source: CHGIS (2007).

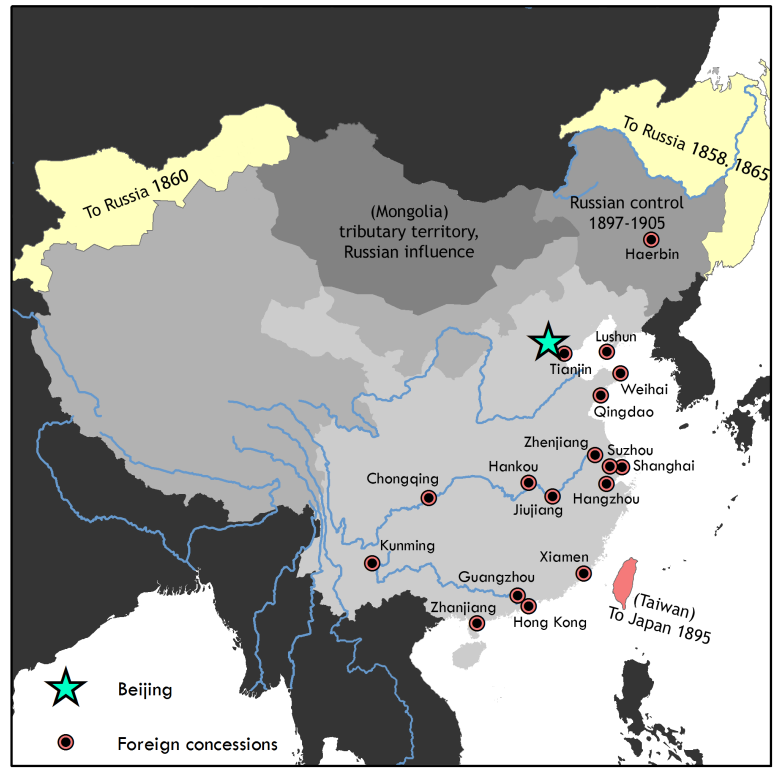

(b) From the mid-1800s to its collapse in 1912, the Qing state faced foreign encroachment by land (from Inner Asia) and by sea (from the sea).

literature points out that external threats and war can encourage investments in state building but it does not explain how the same set of geopolitical threats can have a different impact in different countries. In this section we outline the geopolitical situation facing China and Japan in the nineteenth century and how they responded to the new challenges posed by the West.

Before 1850, the Qing dynasty (1644-1912) ruled a large empire stretching across 14 million square kilometers. Despite its territorial size, political authority was concentrated in the hands of the emperor who ruled through a centralized bureaucracy that had a stronger presence in North China than in South China (Figure 1a). Officials were recruited via imperial examination and selection was meritocratic. There was no hereditary nobility and no separation of social classes (Fairbank, 1992). In comparison to Tokugawa Japan, China had a long legacy of organized rule by a central government. It should have been easier for China to maintain a centralized system of government than it was for Japan to build one as Asia transitioned into the modern era. Nevertheless, this was not what occurred. 
Table 1: Timeline for late Qing China

\begin{tabular}{lll}
\hline Year & Event & Description \\
\hline $1839-42$ & Opium War & China cedes Hong Kong to Britain. \\
$1850-64$ & Taiping Rebellion & Peasant uprising sweeps southern China. \\
$1856-60$ & Second Opium War & Anglo-French expedition defeats Qing Army. \\
1858 & Treaty of Aigun & China cedes $600,000 \mathrm{~km}^{2}$ to Russia. \\
$1861-95$ & Self-Strengthening Movement & China launches limited reforms. \\
$1894-95$ & Sino-Japanese War & China cedes Taiwan and pays huge indemnity. \\
$1899-1901$ & Boxer Rebellion & Eight-Nation Alliance invaded North China. \\
$1901-12$ & New Policies Unveiled & Qing court announces Meiji-style political, \\
& & economic, military, and educational reforms. \\
$1911-12$ & Chinese Revolution & Provinces take opportunity of mutiny in \\
& & Wuchang to declare independence. \\
\hline
\end{tabular}

\subsection{External Threats and State Disintegration in Qing China}

A large existing literature links China's long tradition of political centralization to the recurring geopolitical threat that it faced from the Eurasian steppe (Barfield, 1989; Turchin, 2009). Prior to the Opium Wars, all major invasions of China came via the north. This changed drastically after the First Opium War (1839-42). China's defeat in the hands of Britain meant that the Western powers now posed a direct threat to China's coast. The Treaty of Nanking, signed in 1842 to restore peace, saw the establishment of Hong Kong as a British colony and the opening of Shanghai and other Chinese ports to foreign trade and residence. It was followed by a series of "unequal treaties" that committed China to grant extraterritorial rights and give up tariff autonomy to the Western powers. Table 1 summarizes the chronology of these events.

Besides confronting unprecedented naval threats from the sea, China also had to deal with steady encroachment by Russia, who had by now replaced the steppe nomads as China's main threat along its north-west land frontier. In 1858, when fighting a joint Anglo-French invasion, China ceded its territories north of the Amur River to Russia to avoid fighting a two-front war (Figure 1b). Further Russian encroachment precipitated what historians referred to as "the great policy debate of 1874," which saw senior Chinese statesmen in disagreement over whether China should place its defense priority on its land or maritime frontiers (Liu and Smith, 1980). ${ }^{5}$

\footnotetext{
${ }^{5}$ The contemporaneous Blackwood's Edinburgh Magazine observed in its July 1852 issue that China was increasingly sandwiched between foreign pressures along its north-west frontier and along its south-east coast. On the one hand, "Russia, the great nascent power of the Old World, has rolled her armies across Siberia up to the foot of the Great Wall, and now casts a covetous eye upon the northern portion of the Celestial Empire". On the other hand, "Britain [...] has reached with her fleets every harbour of the Flowery Land" (113).
} 
The geopolitical changes coincided with a shift toward limited political decentralization within China, which first took place in the 1850s to provide a more flexible and responsive approach to counter the Taiping Rebellion (Kuhn, 1980). Apart from allowing provincial scholar-generals to raise their own armies, the imperial court also granted them more fiscal autonomy (Shi and $\mathrm{Xu}, 2008$ ). After the rebels were put down, political decentralization was partially but not fully rolled back as the provinces continued to enjoy substantial autonomy on fiscal and administrative matters. ${ }^{6}$ To deal with the rising Western threat, the imperial court permitted some provincial appointment holders to undertake greater responsibilities in foreign affairs. In particular, the viceroy of Zhili province was entrusted with the responsibilities of coordinating defense matters in the coastal provinces and dealing with the Western powers (Chu and Liu, 1994).

The Qing state also initiated the Self Strengthening Movement in the 1860s. Some of its more significant endeavors include: setting up foreign language schools in Beijing, Shanghai, and Guangzhou to build foreign affairs expertise and to translate Western works of science and technology; opening new mines and constructing iron foundries, steel mills, machine factories, arsenals, and shipyards; the establishment of military and naval academies; creating new industries and enterprises including railway and telegraph lines, cotton-spinning and weaving companies, and steam navigation companies.

Its achievements notwithstanding, the Self Strengthening Movement was largely confined to the adoption of Western military technology and armaments. It was significantly less ambitious in agenda and limited in terms of its social and economic impact when compared with Japan's Meiji Restoration, where reforms went beyond military modernization and involved, among other things, an overhaul of the land ownership system, the introduction of compulsory education, and state-led investment on a nationwide rail transport network (Jansen, 2000). As Figure 2 illustrates, China lagged behind Japan in railroad construction in the run-up to the Sino-Japanese War of 1894-5. In the construction of telegraph lines, setting up of post offices, and use of steamships too, China was overshadowed by its eastern neighbor $(\mathrm{Li}, 2008){ }^{7}$

A major impediment to reform in late-Qing China was the significant disagreement within the political leadership. Reformers in the government were often attacked and labeled as traitors and sycophants by conservative and hardline officials, who argued against the need for China to change its institutions and practices (Hao and Wang, 1980).

The general public, too, displayed significant resentment toward what they perceived as foreign encroachment on China (Baark, 1997; Rowe, 2009). Anti-missionary riots and assaults

\footnotetext{
${ }^{6}$ For quantitative evidence, see Shi $(2009,59)$.

${ }^{7}$ Moreover, even the achievements of the Self Strengthening Movement such as the Fuzhou Shipyard was undermined by the absence of a centralized fiscal system and reliance on ad hoc local financing arrangements as documented by Pong (1987).
} 
Figure 2: Railroad construction in Qing China and Meiji Japan
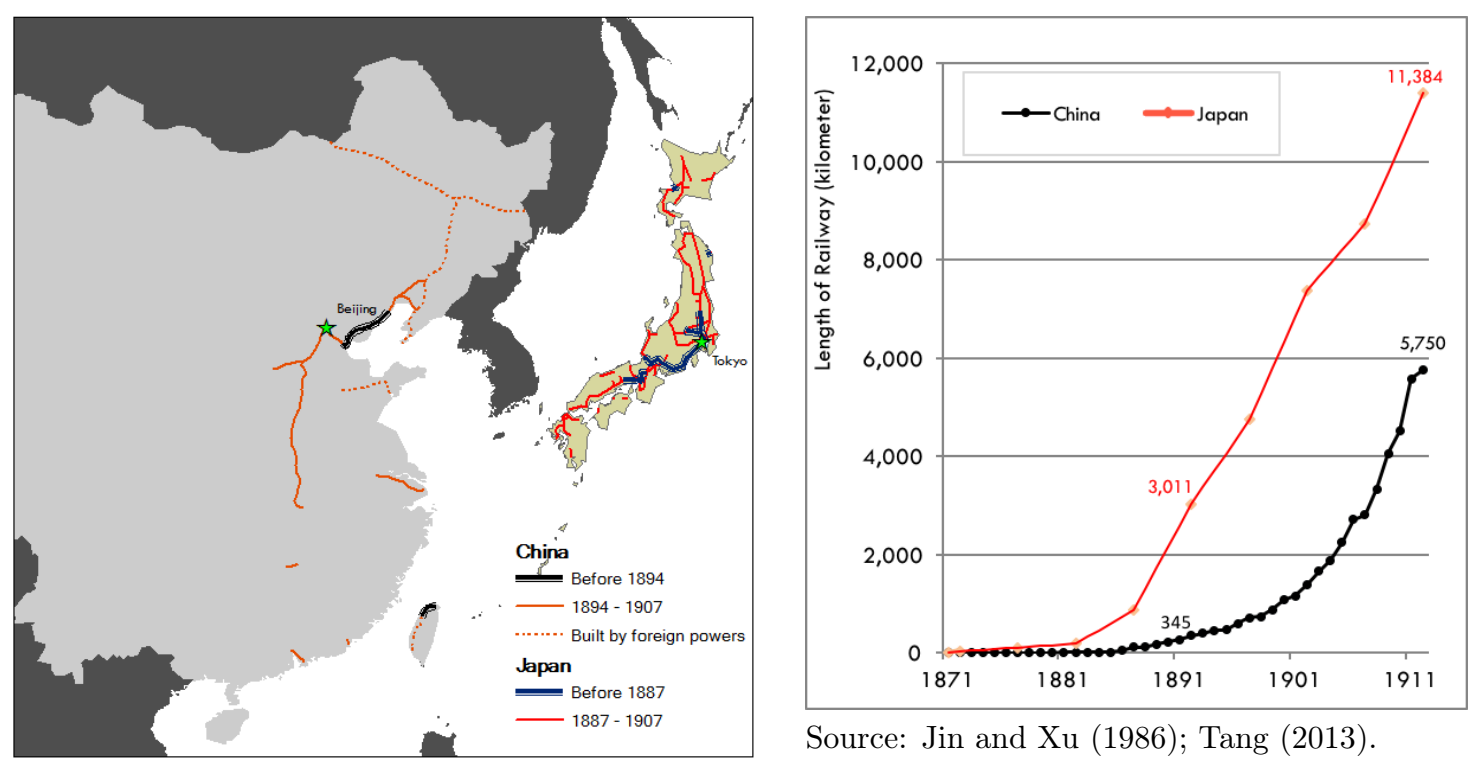

occurred periodically and received support from the gentry and commoners, who viewed the missionaries and hitherto unknown technologies such as telegraphs and railways with grave suspicion. ${ }^{8}$ China's first operational railway, the 14.5-kilometer Wusong Railway, was torn down in 1877 amid unrest among the local population (Wang, 2015).

After China's comprehensive defeat at the hands of Japan in 1894-95, its political leadership began to contemplate a major overhaul of the existing institutions (Hao and Wang, 1980). In the early 1900s, the imperial court announced Meiji-style reforms in government, military, education, and other areas. However, the dynasty collapsed in 1912 after a mutiny in Wuchang triggered a chain of events that caused the provinces to declare their independence from Beijing.

\subsection{From Tokugawa to Meiji Japan}

During the Tokugawa period (1603-1868), Japanese society was organized into four hereditary classes of samurai, farmers, artisans, and merchants. The emperor was merely a figurehead while the shogun, the most powerful lord in Japan, ruled only $15 \%$ of the country directly (Figure 3). The bulk of the remaining country was territorially divided into some 260 domains, each headed by a local lord (daimyo).

Most of these domains were very small. In the 1860s, 166 out of the 266 domains had

${ }^{8}$ Wright $(1957,274)$ observed that "Christianity in the 1860 's was attacked not [... by officials, but by the populace and non-office-holding lower literati; it was menaced not be proscription but by mob riots." 
Figure 3: Japan before the Meiji Unification.

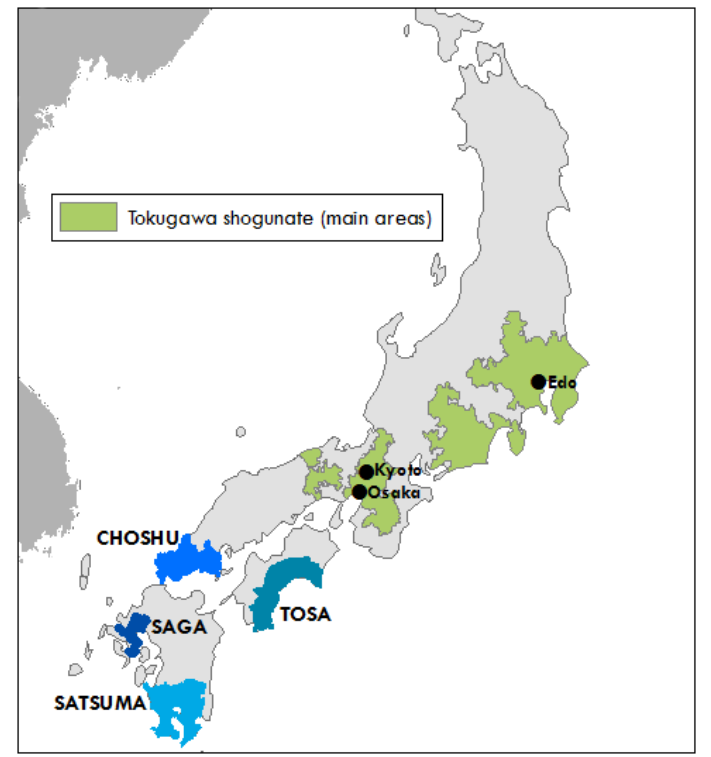

(a) Adversaries of Boshin War

\begin{tabular}{lr}
\hline Domain & Annual Output (koku) \\
\hline Shogunate & $4,000,000$ \\
Kaga & $1,350,000$ \\
Choshu & 990,000 \\
Satsuma & 870,000 \\
Kumamoto & 790,000 \\
Owari & 780,000 \\
Saga & 720,000 \\
Fukuoka & 570,000 \\
Kii & 540,000 \\
Tosa & 500,000 \\
\hline
\end{tabular}

Notes: (i) Data source: Hansei ichiran. Map adapted from http://www.fas.harvard.edu/ chgis/japan/; (ii) Output of Shogunate based on official estimate, others are actual outputs in 1869; (iii) Anti-Shogunate coalition in bold.

(b) Largest domains by output

annual outputs below 50,000 koku. ${ }^{9}$ By comparison, the Shogunate was rated at 4 million koku. However, there were eighteen sizable local domains. Their lords were regarded as "province holders" (kunimochi daimyo) by contemporaries and behaved "more like sovereigns than like vassals" (Ravina, 1999, 21). Four of these domains - Satsuma, Choshu, Saga, and Tosa - would form the coalition that overthrew the Shogunate in 1868 (Figure 3b).

Before the late Tokugawa period, the Shogunate was able to maintain a monopoly over foreign and inter-domain affairs. However, there was no central treasury in Tokugawa Japan, nor was there a central army (Jansen, 2000). The Shogunate had no right to tax other domains and the local domains maintained their own administrators, armies, tax systems, and legal codes (Totman, 1993). Many domains issued their own paper monies or copper cash. The absence of fiscal and military institutions at the national level and the autonomy of local domains implies that Tokugawa Japan was fiscally and militarily fragmented. If we accept Max Weber's definition of a modern state as an entity claiming a monopoly of legitimate violence, Tokugawa Japan was not a single state but comprised a league of smaller political entities (Weber, 1968). ${ }^{10}$

Due to fear of foreign influence, the Shogunate outlawed Christianity and banned Japanese

\footnotetext{
${ }^{9}$ Japanese domains were measured in terms of economic output instead of land area. One koku is equivalent to 180.4 liters of rice, historically interpreted as the amount required to feed a person for a year.

${ }^{10}$ See Sng and Moriguchi (2014) for a similar argument. Further support of this interpretation comes from the theory of the firm, which equates ownership with the control of residual rights to assets (Grossman and Hart, 1986). Since a daimyo was the residual claimant to the fiscal resources of his domain, he, not the shogun, owned the domain.
} 
Table 2: Timeline for Major Events in late Tokugawa and early Meiji Japan

\begin{tabular}{|c|c|c|}
\hline Year & Event & Description \\
\hline 1853 & Black Ships Incident & $\begin{array}{l}\text { American ships arrive off coast of Japan and de- } \\
\text { mands the opening of Japan. }\end{array}$ \\
\hline 1862 & Namamugi Incident & $\begin{array}{l}\text { Satsuma's assault on British nationals results in } \\
\text { bombardment of its capital Kagoshima. }\end{array}$ \\
\hline 1864 & Shimonoseki Campaign & $\begin{array}{l}\text { British, French, Dutch, and American ships bombard } \\
\text { Choshu. }\end{array}$ \\
\hline 1868 & Meiji Restoration & $\begin{array}{l}\text { Tokugawa forces defeated in civil war; Anti- } \\
\text { Shogunate coalition forms government. }\end{array}$ \\
\hline $1871-73$ & Reform accelerates & $\begin{array}{l}\text { Introduction of new currency system, land tax, pub- } \\
\text { lic education, and universal conscription. }\end{array}$ \\
\hline 1877 & Satsuma Rebellion & 80,000 disaffected samurai revolt against reforms. \\
\hline $1894-95$ & Sino-Japanese War & Japan defeats the Chinese army and navy. \\
\hline
\end{tabular}

ships from traveling abroad. Only Chinese and Dutch ships were permitted to enter Nagasaki, the sole major port open to foreign trade before 1858. As geopolitical threats were relatively subdued, the seclusion policy was enforced with relative ease until the 1850s.

Things changed radically in the mid-nineteenth century after a small British expeditionary force defeated China, the traditional linchpin of East Asian political order, in the Opium War (Table 2). In 1853, when a navy squadron from the United States led by Commodore Matthew Perry sailed into Edo bay and demanded that Japan open up or risk war, the Shogunate had no choice but to acquiesce. The event became known as the Black Ships Incident. Subsequently, in a series of treaties signed with various Western powers, the Shogunate further accepted provisions that obliged Japan to open its ports, give up its right to set tariffs on imports, and allow foreigners to enjoy extraterritoriality in Japan (Beasley, 2000).

The Shogunate's perceived weakness and capitulation to the demands of the foreigners led to dissent among the domains. In 1868, Satsuma, Choshu, Saga, and Tosa joined forces to defeat the Shogunate and return power to the Meiji emperor.

Although the anti-Shogunate domains adopted a patriotic, anti-West stance during the civil war, once in power they discarded their xenophobic rhetoric and pursued a program of Westernization that had begun during the last years of the Shogunate. ${ }^{11}$ Feudalism was abolished as local domains were converted into prefectures.Helped by the swift formation of a genuine

\footnotetext{
${ }^{11}$ Japan's naval modernization began in the last decade of Tokugawa rule. Likewise, the plan to construct Japan's first railway between Edo (Tokyo) and Yokohama was approved before the Meiji Restoration. According to Beasley $(2000,50)$, the Shogunate's reform program "was a blueprint for 'wealth and strength' on the lines which the Meiji government was later to follow."
} 
central government, reforms on land, education, monetary, and other areas were implemented on a national scale in a short span of time (Jansen, 2000).

While Japan's political and economic transformation during the Meiji era is widely regarded today as a textbook case of successful modernization and industrialization, it is worth noting that like China, the general population in Japan - samurai and peasants alike - demonstrated considerable xenophobia and resistance to reform too. In 1873-74, several peasant-led revolts against the new land tax, public education, and conscription were brutally quelled. ${ }^{12}$ They were followed by uprisings of samurai who resented the loss of their stipends and their right to carry swords. In 1877, the Satsuma Rebellion, the best known and the last of the post-Meiji uprisings, was decisively suppressed.

The above historical discussion can be summarized as follows:

Observation 1 (Geopolitics): Before the mid-nineteenth century, China's main geopolitical challenge came from Inner Asia, while Japan enjoyed a largely peaceful external environment. In the second half of the nineteenth century, both countries were encroached by the Western powers.

Observation 2 (Political Structure): At the turn of the mid-nineteenth century, China moved from political centralization toward decentralization, whereas Japan shifted from political decentralization to centralization.

Observation 3 (Reform): (a) In response to the Western threat, Japan adopted comprehensive reforms from the onset while China's reforms were limited before the 1900s; (b) The Chinese leadership was divided over the need for reform, while the difference in attitude toward reform between the Shogunate and the anti-Tokugawa leaders was considerably smaller; (c) In both countries, there was considerable public resistance toward reform, but in Japan the state took resolute actions to overcome such resistance.

In the next section, we build a theoretical framework to show how geopolitics (Observation 1) interacted with domestic constraints to shape the different responses we observe in China and Japan (Observations 2 and 3).

\section{MODEL}

We first develop a basic model in which the authority (or ruler) administering a territory chooses where to build state capacity and how much to build to deal with external threats (Section 3.1).

\footnotetext{
${ }^{12}$ As in the Chinese case, ignorance and fear played an important role in these events. In Okayama, Kagawa, and Tottori prefectures, for example, the revolts were fed by rumors that the government was extracting blood and transmitting it via the newly constructed telegraph lines to blood-drinking foreigners (Tanaka, 2004).
} 
We show that the optimal political structure (i.e., centralization or decentralization), depends on two factors: the size of the territory and the nature (i.e., intensity and directions) of the external threats.

Next, we extend the model to incorporate the authority's decision to implement reform on top of providing national defense (Section 3.2). The extension produces the key insight that, when confronting powerful threats from multiple fronts, the difficulty of reconciling the two goals of defense and development increases with the size of the territory.

Finally, we provide a simulation to demonstrate that our model produces the outcomes that are compatible with historical developments in China and Japan (Section 3.3).

To focus on the key mechanisms of the model, we assume simple parametric forms for all functions. However, the results do not depend on the parametric assumptions chosen. In the Appendix, we provide a more general model without these assumptions.

\subsection{Basic Model}

Consider a territory represented by a line of length $[0, \chi]$ with homogeneous inhabitants of mass $\chi$ uniformly distributed along this line. This territory may be as small as the Japanese main islands or as large as China east of the Himalayas and south of the Gobi desert. An inhabitant at point $x \in[0, \chi]$ is endowed with taxable income $y$.

This territory is a state with one or multiple autonomous political authorities. That is, the territory is divided into $S \in \mathbb{N}$ disjoint intervals, each taxed by an authority. For example, before $1850, S=1$ in China and $S>260$ in Japan.

First, we analyze how resilient is a state of $S$ authorities given the geopolitical environment. A higher $S$ represents greater decentralization. For ease of illustration, we assume that $S$ can only take the values of 1 (centralization) or 2 (decentralization). When $S=1$, we refer to the sole authority as Authority $c$. When $S=2$, we refer to the two authorities as Authority $l$ (left) and Authority $r$ (right). ${ }^{13}$

We integrate geopolitical considerations into the analysis in the following way: the territory faces exogenous geopolitical threats from outside. Such threats may be (i) non-existent, (ii) one-sided and emanating from one frontier (at $x=0$, without loss of generality), or (iii) two-sided and emanating from both frontiers (at $x=0$ and $x=\chi$ ).

An external threat, if realized, causes gross damage $\Lambda>0$ at the frontier. If unstopped, the damage will spread further into the territory: for a point $t$ distance away from the frontier, the gross damage is $\lambda(t)=\max \{\Lambda-\alpha t, 0\}$ where $\alpha>0$ inversely measures the spillover strength of the threat (Figures 4 and 5). We assume that military power weakens over distance and

\footnotetext{
${ }^{13}$ Restricting our focus to $S \leq 2$ is innocuous. In Section 5 , we discuss how relaxing it can enrich our results.
} 


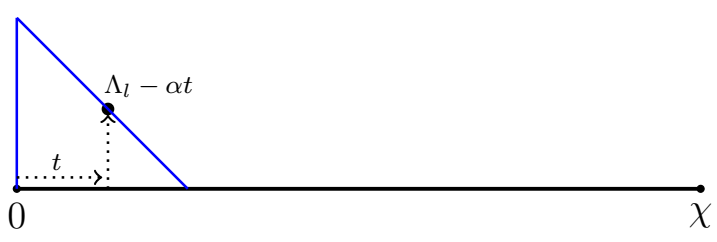

Figure 4: A one-sided threat.

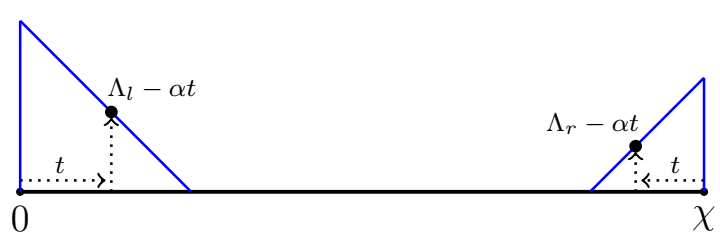

Figure 5: Two-sided (asymmetric) threats.

therefore $\alpha$ is strictly positive. We expect $\alpha$ to be larger in the premodern age than today due to advancement in transportation technology and military weaponry.

Each authority collects taxes and invests in state capacity, which includes both military and administrative infrastructures, to maintain political order. State capacity is strongest at the authority's political-military center, but deteriorates over distance due to constraints imposed by premodern transportation and communication technologies. Let $G_{i}$ denote authority $i$ 's political-military center-referred to here as $i$ 's base. As illustrated in Figure 6, for a location $t$ distance away from $G_{i}$, its state capacity at the location is given by $m(t)=\max \left\{M_{i}-\beta t, 0\right\}$, where $\beta>0$ captures the deterioration of state capacity due to distance. Note the analogy between $\alpha$ and $\beta$.

State capacity can block the external threat from spreading inland. Specifically, consider a one-sided threat initiated at $x=0$, if the state capacity of authority $i$ at $x^{\prime}$ is no less than the gross damage of the external threat at that location, then $x^{\prime}$ and any location to its right is said to be protected (Figure 7). For authority $i \in\{c, l, r\}$ to invest $M_{i} \geq 0$, it costs $m_{0}+\theta M_{i}^{2}$, where $m_{0}>0$ denotes the fixed cost of capacity building and $\theta>0$ is a scaling constant.

Authorities that do not adequately protect their populations face civil unrest. Clearly, if unrest is sufficiently widespread, the existing political order will collapse. To model this, we assume that if a contiguous segment of length more than $0<\delta<1$ is left unprotected, then a revolution occurs and the authority that taxes the segment collapses. ${ }^{14}$ This assumption, commonly used in models of political economy, captures the observation that no government regardless of regime type can completely ignore the welfare of its subjects, but revolutions require sizable support to make an impact (Alesina and Spolaore, 2003).

Under political centralization $(S=1)$, the centralized authority $c$ controls the entire territory and its net tax revenue is $V_{c}=\chi y-m_{0}-\theta M_{c}^{2}$. Under political decentralization $(S=2)$, we fix the administrative border of the two local authorities at $\frac{1}{2} \chi$. The left authority $l$ chooses its base location $G_{l} \in\left[0, \frac{1}{2} \chi\right]$. The right authority $r$ chooses its base location $G_{r} \in\left[\frac{1}{2} \chi, 1\right]$. Their net revenues are $V_{l}=\frac{1}{2} \chi y-m_{0}-\theta M_{l}^{2}$ and $V_{r}=\frac{1}{2} \chi y-m_{0}-\theta M_{r}^{2}$ respectively. Endogenizing border formation will not affect our results and in the Appendix, we provide a model that allows

\footnotetext{
${ }^{14}$ This assumption generalizes but does not drive the results. Removing it is equivalent to setting $\delta=0$.
} 


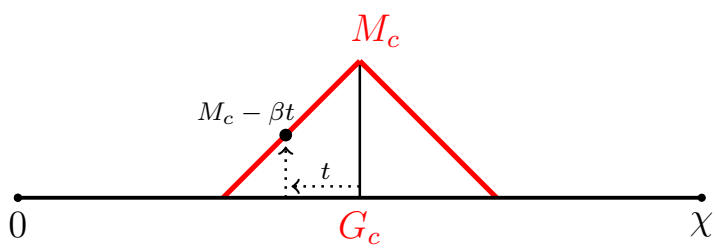

Figure 6: An authority's state capacity deteriorates over distance from its base.

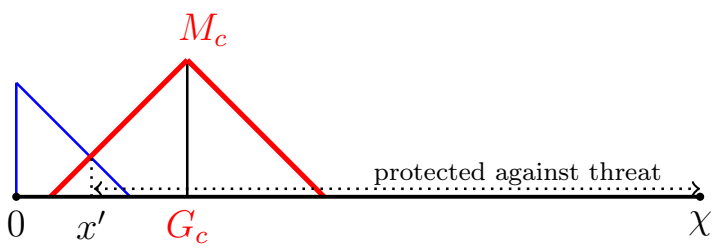

Figure 7: Authority $c$ blocks the external threat at $x^{\prime}$ so that the interval from $x^{\prime}$ to $\chi$ is protected.

authorities to compete for territory.

The optimization problems under political centralization and decentralization are as follows: the centralized state $c$ chooses the location of its base $G_{c} \in[0,1]$ and invests $M_{c} \geq 0$ to maximize its net revenue; authorities $l$ and $r$ simultaneously choose their bases $G_{l} \in\left[0, \frac{1}{2} \chi\right]$ and $G_{r} \in\left[\frac{1}{2} \chi, \chi\right]$ and make investments $M_{l} \geq 0$ and $M_{r} \geq 0$ to maximize their respective net tax revenues.

We now present the solutions of the above optimization problems in the form of four propositions, which respectively address political centralization under one-sided threat (P1) and two-sided threats (P2), and political decentralization under one-sided threat (P3) and two-sided threats (P4). Subsequently, we derive two implications from these propositions to compare the resilience of political centralization and decentralization under different threat scenarios.

Proposition 1 (Centralization, One-Sided Threat). Let $\bar{\Lambda}=\alpha \delta$.

When the threat is one-sided and emanates from $x=0$ :

A. If $\Lambda_{l} \leq \bar{\Lambda}$, the centralized state locates the base at $G_{c} \in\left[\frac{\Lambda_{l}}{\alpha}, \chi\right]$ and makes zero investment in state capacity;

B. If $\Lambda_{l}>\bar{\Lambda}$, the centralized state locates the base at $G_{c}=\delta$ and invests to the level $M_{c}=\Lambda_{l}-\alpha \delta$.

Consider a politically centralized territory under a one-sided threat. Case A states that if the threat is trivial (i.e., it brings gross damage to no more than $\delta$ segment of the territory), the centralized state will ignore it and make minimal effort to build state capacity. One could argue that Japan of the Nara period (710-784) or the Heian Period (794-1185) epitomize this case. Case B characterizes the scenario that China confronted in the late imperial period during which it located its capital city (Beijing), bureaucracy, and military close to the northern border to defend the steppe threat.

Next, consider a centralized state confronting two geopolitical threats. Without loss of generality, assume that $\Lambda_{l}>\Lambda_{r}$ when $\Lambda_{l} \neq \Lambda_{r}$. 
Proposition 2 (Centralization, Two-Sided Threats). Let $\bar{\Lambda}=\alpha \delta$.

Under threats from both $x=0$ and $x=\chi$ :

A. If $\Lambda_{l} \leq \bar{\Lambda}$ and $\Lambda_{r} \leq \bar{\Lambda}$, the centralized state locates the base at $G_{c} \in\left[\frac{\Lambda_{l}}{\alpha}, \chi-\frac{\Lambda_{r}}{\alpha}\right]$ and makes zero investment in state capacity;

B. If $\Lambda_{l}>\bar{\Lambda}$ and $\Lambda_{r} \leq \bar{\Lambda}$, the centralized state locates the base at $G_{c}=\delta$ and invests to the level $M_{c}=\Lambda_{l}-\alpha \delta$;

C. If $\Lambda_{l}>\bar{\Lambda}$ and $\Lambda_{r}>\bar{\Lambda}$, the centralized state locates the base at $G_{c}=\frac{\chi}{2}+\frac{\Lambda_{r}-\Lambda_{l}}{2 \beta}$ and invests to the level $M_{c}=\frac{\Lambda_{r}+\Lambda_{l}}{2}+\frac{\beta \chi}{2}-(\alpha+\beta) \delta$.

Cases A and B of Proposition 2 are analogous to Cases A and B of Proposition 1. In Case A, both threats are trivial and the centralized state makes zero investment in state capacity. In Case $\mathrm{B}$, because the threat arising from $x=\chi$ is trivial, the centralized state focuses on dealing with the threat at $x=0$ only. Of particular interest is Case $\mathrm{C}$, where threats on both ends of the territory are non-trivial. In this situation, the state locates its base close to the center of the territory to deal with both threats simultaneously.

Moving on to political decentralization. Propositions 3 and 4 mirror Propositions 1 and 2 respectively:

Proposition 3 (Decentralization, One-Sided Threat). Let $\bar{\Lambda}=\alpha \delta$.

Under an external threat emanating from $x=0$ :

A. If $\Lambda_{l} \leq \bar{\Lambda}$, Authority l locates its base at $G_{l} \in\left[\frac{\Lambda_{l}}{\alpha}, \frac{1}{2} \chi\right]$; Authority $r$ locates its base at $G_{r} \in\left[\frac{1}{2} \chi, \chi\right]$; each makes zero investment in state capacity.

B. If $\Lambda_{l}>\bar{\Lambda}$, Authority l locates its base at $G_{l}=\delta$ and invests to the level $M_{l}=\Lambda_{l}-\alpha \delta$; Authority $r$ locates its base at $G_{r} \in\left[\frac{1}{2} \chi, \chi\right]$ and makes zero investment in state capacity.

Proposition 4 (Decentralization, Two-Sided Threats). Let $\bar{\Lambda}=\alpha \delta$.

Under threats from both $x=0$ and $x=\chi$, Authority $l$ responds in the manner specified in Proposition 3. As for Authority $r$ :

A. If $\Lambda_{r} \leq \bar{\Lambda}$, it locates its base at $G_{r} \in\left[\frac{1}{2}, \chi-\frac{\Lambda_{r}}{\alpha}\right]$ and makes zero investment in state capacity.

B. If $\Lambda_{r}>\bar{\Lambda}$, it locates its base at $G_{r}=\chi-\delta$ and invests to the level $M_{r}=\Lambda_{r}-\alpha \delta$. 


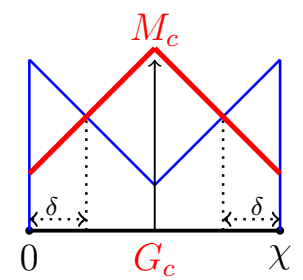

Figure 8: When the territory $(\chi)$ is small, political centralization pools scarce resources to deal with two-sided threats efficiently.

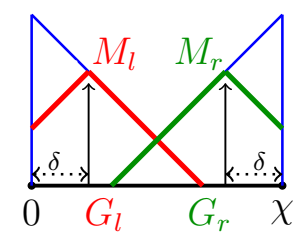

Figure 9: Political fragmentation generates wastage and heightens the problem of resource scarcity in a small territory.

In Case A of Propositions 3 and 4, the threat confronting the authority is trivial and can be safely ignored. This is no longer true in Case B, and hence the local authority will locate its base strategically and invest in state capacity to contain the threat.

With Propositions 1-4, we can analyze how the nature of external threats determines the optimal political structure (centralization or decentralization) of the state. Specifically we can establish the following results.

Implication 1 (One-Sided Threat).

For any $\Lambda_{l}>0, V_{c}^{*} \geq V_{l}^{*}+V_{r}^{*}$ and $V_{c}^{*}>V_{l}^{*}$.

Since the state requires revenues to sustain itself, it is prone to collapse when its finances are weak. Implication 1 states that when the threat is one-sided, political centralization is more resilient than political decentralization. The intuition is simple: a one-sided geopolitical threat severe enough to bankrupt Authority $l$ under political decentralization may not overwhelm a centralized authority $c$. This highlights the advantage of political centralization: it allows for resource pooling to deal with common threats to the territory because Authority $c$ can mobilize the taxable resources of the entire territory while Authority $l$ can only mobilize half of it.

Implication 2 (Two-Sided Threats).

A. For any $\Lambda_{l}>\bar{\Lambda}$ and $\Lambda_{r}>\bar{\Lambda}$, there exists threshold value $\underline{\chi}\left(\Lambda_{l}, \Lambda_{r}\right)$ such that if $\chi<\underline{\chi}\left(\Lambda_{l}, \Lambda_{r}\right)$ then $V_{l}^{*}+V_{r}^{*}<V_{c}^{*}$.

B. For any $\Lambda_{l}>\bar{\Lambda}$ and $\Lambda_{r}>\bar{\Lambda}$, there exists threshold value $\bar{\chi}\left(\Lambda_{l}, \Lambda_{r}\right)$ such that if $\chi>\bar{\chi}\left(\Lambda_{l}, \Lambda_{r}\right)$ then $V_{c}^{*}<V_{l}^{*}+V_{r}^{*}$.

While political centralization is always more resilient than political decentralization under a one-sided threat, under two-sided threats the relative resilience of centralization and decentralization depends on $\chi$, the size of the territory. Implication $2 \mathrm{~A}$ states that if the territory is 


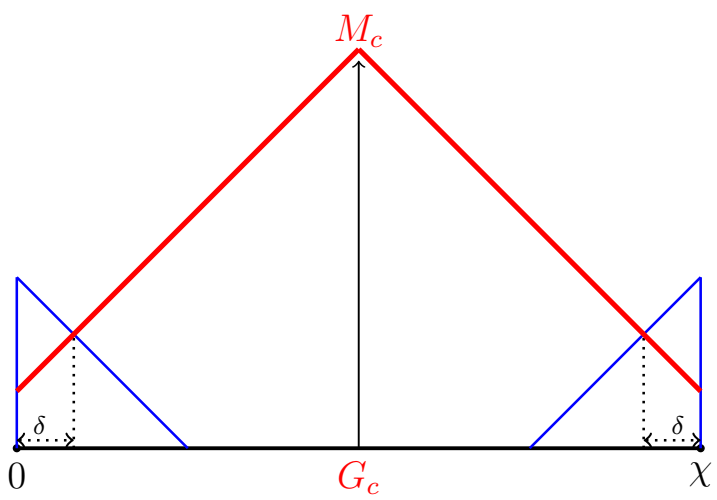

Figure 10: When the territory $(\chi)$ is large, a unified state has to make colossal investment to deal with twosided threats.

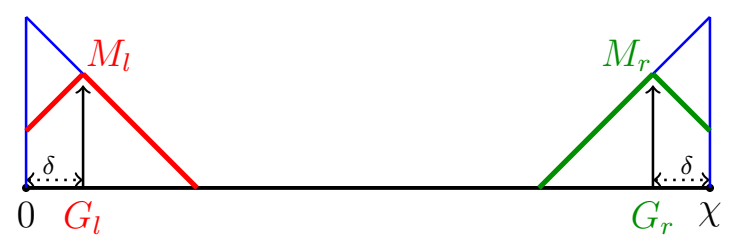

Figure 11: When the territory $(\chi)$ is large, a division of labor between authorities $l$ and $r$ helps contain the cost of dealing with two-sided threats.

sufficiently small, then political centralization is always preferred to decentralization - having a centralized state to protect both fronts (Figure 8) is more cost effective than having two local authorities dividing up the territory's scare resources to make repetitive investments (Figure 9).

However, the reverse is true for a large territory. Implication 2B states that when the territory is large and the threats are far apart, having two authorities, each taking on one threat, is preferred to centralization because the cost of having a single authority simultaneously defending both frontiers is exorbitantly high (Figures 10 and 11).

Hence, when facing severe two-sided threats, a small territory has a strong incentive to centralize, while a large territory has a strong incentive to decentralize.

\subsection{Extension: To Reform Or Not?}

We now extend the model to introduce the decision to implement socioeconomic reform, which is a set of policies necessary to modernize the economy such as conducting a thorough land survey, clarifying parcel boundaries and formalizing land rights, suppressing bandits and secret societies, breaking up local distributional coalitions, and restraining the rent-seeking power of special interest groups.

The timing of events is as follows: First authority $i$ decides the location of its base $G_{i} \in[0,1]$ and state capacity investment $M_{i} \geq 0$. Next, it decides whether to implement reform, which changes taxable income from $y$ to $\bar{y}$. Since this is a two-stage decision process, we employ backward induction to solve it.

In practice, reform entails social dislocation and creates losers as well as winners, the losers will attempt to block the changes that hurt their interest unless they are adequately compensated 


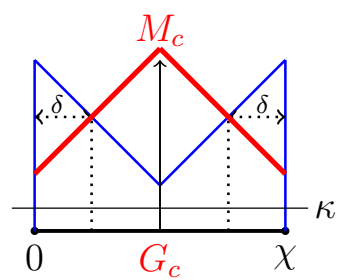

Figure 12: A politically centralized territory has state capacity (depicted in red) higher than $\kappa$ everywhere. No extra investment is required to manage the reform process.

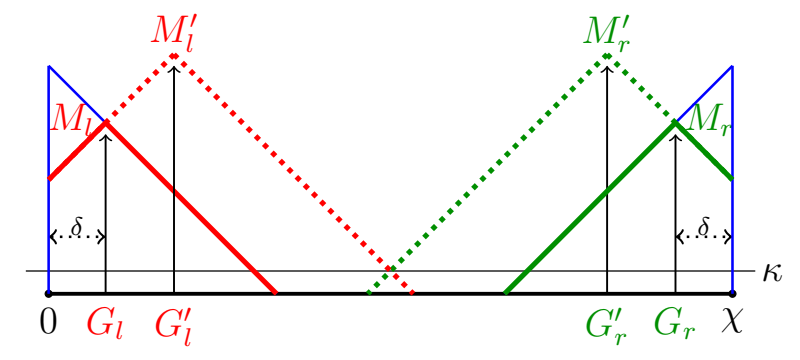

Figure 13: When the territory is large, authorities $l$ and $r$ have to make extra investments to extend their state capacities inland should they decide to pursue economic reform.

(Olson, 1963; Acemoglu and Robinson, 2000; Coşgel et al., 2012). In such situations, strong political and social institutions could help overcome resistance from vested interests and from local inertia through a mix of persuasion and coercion. To model this, we assume that an authority is capable of pushing through reform only if its state capacity throughout the segment it controls is no less than $\kappa>0$. We expect $\kappa$ to be relatively small compared with $\Lambda$, since suppressing a local rebellion should be a lesser challenge than fighting a colonial power.

Implication 3 (Reform).

Under non-trivial two-sided threats $\left(\Lambda_{l}>\bar{\Lambda}\right.$ and $\left.\Lambda_{r}>\bar{\Lambda}\right)$ :

A. If the territory is politically centralized, reform will be implemented if $\bar{y}-y>0$;

B. If the territory is politically decentralized and $\chi \leq 2\left(\frac{\Lambda-\alpha \delta-\kappa}{\beta}\right)+\delta$, reform will be implemented if $\bar{y}-y>0$;

C. If the territory is politically decentralized and $\chi>2\left(\frac{\Lambda-\alpha \delta-\kappa}{\beta}\right)+\delta$, reform will be implemented if $\frac{1}{2} \chi(\bar{y}-y)+\frac{\theta}{4}\left[(2 \Lambda-2 \alpha \delta)^{2}-\left(\kappa+\frac{\beta \chi}{2}+\Lambda-\delta \alpha-\delta \beta\right)^{2}\right]>0$.

Intuitively, in Case A because a politically centralized authority confronting non-trivial two-sided threats has to invest heavily and build capacity that effectively covers the entire span of the territory, by default it is reform-ready, and will embrace reform as long as the returns to reform $(\bar{y}-y)$ are positive (Figure 12). Similarly, for a small and politically decentralized territory (Case B), the state capacity of authorities $l$ and $r$ will generally span the entire (short) territory. Hence, there is no additional cost to implement reform. However, for a large and politically decentralized territory (Case $\mathrm{C}$ ), the authorities have to make additional investments in state capacity before they are reform-ready (Figure 13). They will reject reform unless the returns are sufficiently large. 
Figure 14: Net Tax Revenues Under Different Configurations

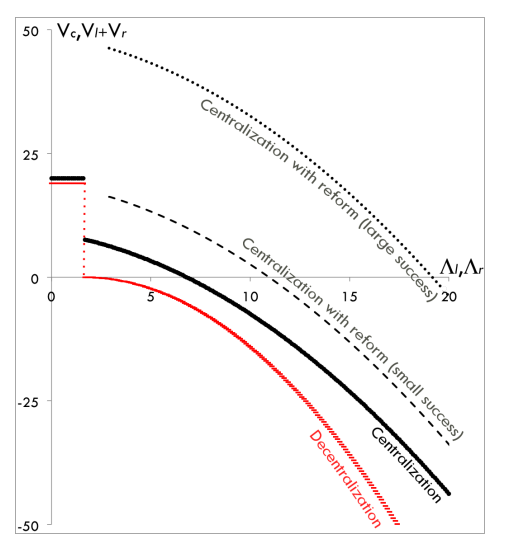

(a) Japan

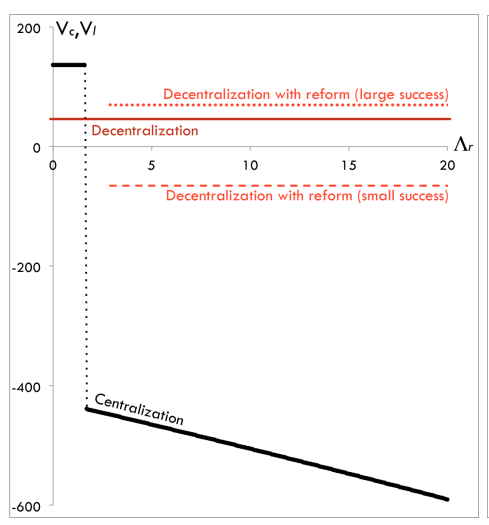

(b) China: Left Authority

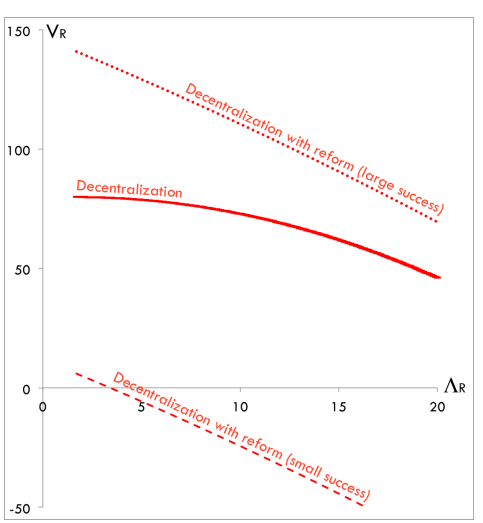

(c) China: Right Authority

\subsection{A Numerical Example}

We provide a simple example to illustrate the two scenarios that are our primary concern. Consider two separate territories, "China" and "Japan." Let $\chi_{\text {China }}=18$ and $\chi_{\text {Japan }}=2$, to represent the 18 provinces in China proper and the two major Japanese regions of Kanto and Kansai. In addition, let $m_{0}=10, \theta=0.1, \alpha=4, \beta=8, \delta=0.4, \kappa=0.1, y=10$, and suppose that reform will increase income to either $\bar{y}=15$ (small success) or $\bar{y}=30$ (large success). ${ }^{15}$

Initially, China faced a severe one-sided geopolitical threat from the left and $\Lambda_{l, \text { China }}=$ $20, \Lambda_{r, \text { China }}=0$, while Japan enjoyed a peaceful external environment and $\Lambda_{l, \text { Japan }}=\Lambda_{r, \text { Japan }}=0$. With the arrival of new geopolitical threats and the opportunity to reform, China now faces an additional threat on its right flank and $\Lambda_{r, \text { China }}>0$, while Japan finds itself confronting two-sided threats and $\Lambda_{l, \text { Japan }}=\Lambda_{r, \text { Japan }}>0$. We vary $\Lambda_{r, \text { China }}, \Lambda_{l, r, \text { Japan }}$, and $\bar{y}$ to explore how they would affect the optimal response in each territory.

Suppose that a negative net tax revenue implies state collapse. As Figure 14a illustrates, for Japan political decentralization is sustainable in the absence of external threats (i.e., $V_{l, \text { Japan }}=$ $V_{r, \text { Japan }}>0$ when $\Lambda_{l, \text { Japan }}=\Lambda_{r, \text { Japan }}=0$ ). However, this is no longer true once new threats emerge. The net tax revenues of the (two) decentralized authorities turn negative at relatively low threat levels (from $\Lambda_{l, \text { Japan }}=\Lambda_{r, \text { Japan }}=1.6$ onward). Centralization and reform offer a better chance of survival. Regardless of how severe the new threats and how small the returns to reform are, the payoff of centralizing and reforming always exceeds that of remaining decentralized and unreformed.

\footnotetext{
${ }^{15}$ These values are chosen for clear interpretation (so that the equilibrium net tax revenues in both territories fluctuates around zero within the range of external threat levels considered). Varying the parameter values will not qualitatively affect the conclusions since the conclusions are based on Propositions 1-4.
} 
As for China, Figure 14b illustrates that once an additional threat emerges on the right and $\Lambda_{r, \text { China }}>1.6$, net tax revenue becomes negative under political centralization. The centralized authority $c$ can avoid collapse if it allows a new authority $r$ to be set up to administer the right half of the territory. Now, should decentralization take place, for the diminished authority $c$ as well as the new authority $r$, the case for reform is not clear cut. Whether reform should be implemented depends on their expectation of its returns. In Figures $14 \mathrm{~b}$ and 14c, reform is worthwhile when $\bar{y}=30$ (reform triples income), but not when $\bar{y}=15$ (reform increases income by $50 \%$ ). Hence, if the returns to reform are ex-ante uncertain, policymakers may disagree over the need to reform if they have different expectations of its returns. ${ }^{16}$

Finally, it is useful to discuss the case of a territory that is smaller than "Japan" $(\chi<2)$. If the territory is very small, regardless of its political structure and with or without reform, its net tax revenue will be negative even at modest threat levels. Hence, our model does not imply that smaller is always better. Japan was smaller than China, but it was larger than Korea, Vietnam, and Sulu, all of which lost their independence to colonial powers despite their long histories of continuous statehood.

\section{Application: Nineteenth Century China and Japan}

Building on the numerical example, we now demonstrate that our model offers a useful framework in organizing and understanding the historical developments discussed in Section 2.

Observation 1: Geopolitics. Our starting point is the changing geopolitical environment in East Asia in the mid-nineteenth century. In our analysis, China corresponds to a large territory initially confronting a severe one-sided threat from the steppe. In contrast, Tokugawa Japan prior to the arrival of the Black Ships was a small territory facing no significant external threats. From the mid-nineteenth century, Russia replaced the steppe nomads as China's main threat along its north-west border while the previously peaceful coastal frontier now faced threats from Western naval powers. Likewise, Japan now faced non-trivial threats arising from both frontiers.

Observation 2: Political Structure. Implication 1 suggests that when China was under one-sided steppe threat, political centralization was optimal. Our model also helps explain the

\footnotetext{
${ }^{16}$ For historical accuracy, one may also assume that the new threats observed in "China" are more severe than in "Japan" (i.e., $\Lambda_{l, \text { China }}>\Lambda_{l, \text { Japan }}$ and $\Lambda_{r, \text { China }}>\Lambda_{r, \text { Japan }}$ ) to reflect the perception that China bore the brunt of Western imperialism due to its closer proximity to Europe and because the size of its market made it a more attractive target (Rowe, 2009). This would not affect our conclusions.
} 
pattern observed in Figure 1a: why, despite a higher concentration of population and wealth in South China, state capacity was located more heavily in the north.

In the 1850s, to suppress the Taiping Rebellion and restore order in the affected provinces, the Qing state devolved decision-making power to provincial administrators. The arrangement was largely preserved in the aftermath of the Taiping Rebellion. To deal with the Western naval powers more effectively, the viceroys of Zhili and Liangjiang, who administered the key coastal provinces, were granted the concurrent appointments of the minister of Beiyang (Northern Seas) and the minister of Nanyang (Southern Seas) respectively. As Implication 2 predicts, the emergence of the maritime threat on top of the traditional threat from Inner Asia pushed China toward political decentralization and the provincial officials responded by spearheading a complete overhaul of China's coastal defense, including the construction of the Beiyang and Nanyang Fleets and new shipyards, arsenals, technical and translation schools, and other defense-related endeavors.

As for Japan, before the intrusion of the West, its fragmented feudal structure was fiscally inefficient but sustainable. However, the wastefulness of dividing a relatively small state into numerous pint-sized domains was exposed once non-trivial external threats emerged. To shore up defenses against the Western naval powers, the coastal domains took steps to bolster their military capabilities, including casting cannons, purchasing firearms, and improving training, which stretched their limited fiscal capacities. As Totman $(1993,535)$ observed, "[...] it appears that the contemporary fiscal difficulties of such domains as Himeiji, Kawagoe, Mito, Tottori, and Tsushima, and possibly Kii, Ogaki, and Owari can be partially attributed to the unusual defense burdens they had recently assumed."

Implication 2 predicts that for a small territory like Japan, the emergence of non-trivial foreign threats would render political fragmentation untenable. Indeed, in the run-up to the civil war, the antagonistic Shogunate and anti-Shogunate forces both sought to restructure the shogunate-domain system. The anti-Shogunate forces rallied under the slogan of sonno jōi (revere the emperor and expel the barbarians), which called for national unification under the emperor and conspicuously omitted any mention of the shogun. The Shogunate, for its part, pursued $k \bar{o} b u$ gattai, or the union of the imperial court and the Shogunate (through marriage) so as to create a genuine central authority. Despite their rivalry, both camps saw national unification as a precondition for Japan to resist further foreign aggression. Beasley $(1973,95)$ noted that it was the Shogunate's plans in 1866-67 to promote political centralization and reform that accelerated the civil war as "Satsuma and Choshu began to fear that they must act quickly or lose their chance." 
Observation 3: Reform. Implication 3 predicts that a small state confronting non-trivial external threats is likely to accept reform (1) to augment it limited resources, and (2) because having already built sufficient state capacity, its marginal cost of reform is low. In the case of Japan, the anti-Shogunate coalition was outwardly xenophobic before the Restoration, but once the civil war was over, they, too, sought to maintain good relations with the West and embraced reform.

To be sure, there was tension among the Satsuma and Choshu factions; reforms were often implemented without a clear, overarching plan and many achievements were the result of trialand-error (He, 2013). But within the ruling class, there was consensus on the untenability of the status quo and a shared fear that resource-poor Japan could be colonized by the West. Much of the disagreement was centered on the speed and method of reform instead of its necessity.

The Meiji state modified and developed the system of political control and local administration that the former shogunate and domain administrations left behind (Nakabayashi, 2012). As a strong state, its ability to deal with local grievances responsively enabled the successful implementation of unpopular policies such as the land tax reform and public education. On the one hand, it was willing to fine-tune its policies to appease dissent without fundamentally compromising the reform agenda. For example, the land tax was lowered to $2.5 \%$ of the land value in 1877 when it became clear that the initial level of $3 \%$ set during the 1873 land tax reform was too heavy for many farmers. ${ }^{17}$ On the other hand, it did not hesitate to squelch any sign of open dissent. The anti-tax, anti-reform uprisings of the 1870s - some of them involving as many as 100,000 farmers - were forcefully suppressed, and the primary instigators were often executed as a warning to others (Aoki, 1971; Duke, 2009).

What about China? Consistent with our model, the rise of the West in the mid-1800s encouraged state building efforts, especially along the coastal provinces. However, the vastness of its territory implies that much of the country remained under-administered. While Japan would see reform as the natural next step after its political centralization, reform in China was impeded by a lack of state capacity at the local level, particularly in the rural interior (Kuhn, 2002).

As Albert Feuerwerker (1980, 59-60) noted, "the imperial bureaucracy, although highly centralized in its formal organization, did not penetrate very deeply into Chinese society [...]." One consequence was the high incidence of anti-missionary riots and assaults on foreigners living in China which the state was often powerless to prevent and could only deal with by paying compensation after the damage had been done (Wehrle, 1966). Unable to take a proactive stance due to its low state capacity, the Qing state behaved reactively. In the eyes of Robert Hart (1975, 118), Inspector-General of China's Imperial Custom from 1863-1908, the imperial court's

\footnotetext{
${ }^{17}$ Similarly, the Meiji government aimed at establishing compulsory education of 8 years in 1872, but it was reduced to 3 years in 1880 in response to peasant protests against the shortage of farm helpers.
} 
policy "was not to guide but to follow events", "what the people wish for [...] the Government in the end sanctions." Popular objections and concerns that telegraph lines, railways, and other new innovations would undermine social stability by inducing land grabs and disputes, throwing porters and peddlers out of work, generating conflicts between locals and foreigners contributed to the imperial court's ambivalent attitude toward reform and hampered China's early industrialization (Fairbank, 1992; Baark, 1997).

Our model highlights that China in the second half of the nineteenth century needed additional local state building and possibly further decentralization before it could manage radical socioeconomic change (Figure 13). Due to the high costs and political risks that reform entailed, these efforts would only be worthwhile if the perceived benefits were huge. Consistent with Implication 3, Chinese enthusiasm toward reform rose after they witnessed in the 1894-5 Sino-Japanese War Japan's rapid transformation into a modern power.

Ironically, the Qing dynasty hastened its demise when it finally committed itself to undertake institutional reform in the 1900s. The newly created provincial assemblies, one of the key components in the reform package, helped end the dynasty by revolting against it in 1911-12. A few years later, China entered the warlord era (1916-28). Although the era has received a bad name due to the constant fighting among armies led by provincial strongmen, it was also a time of intense local state building, when local governments under the warlords built new institutions to tax, regulate markets, and provide public services (Remick, 2004). Mao, who led the communists to national power in 1949, was in fact an advocate of provincial autonomy at this time. In a newspaper article published in 1920, he argued for the breaking up of China into smaller pieces (Mao, 1990),

We have to accept that there is utterly no hope of developing China collectively. The best solution is to forgo the idea of collective development, embrace separatism, allow each province to pursue its own development, and establish the principle of provincial self-determination [...] it is best for China to fragment into 27 countries.

Consistent with our analysis, the Qing state collapsed when the difficulties of resisting foreign aggression and reforming a large country while keeping all the pieces together proved too much for it to manage. The demise of Qing China in 1912 was followed by the fall of Tsarist Russia in 1917 and Ottoman Turkey in 1922. Both empires, like China, were large states that had struggled to implement reforms when confronted with severe geopolitical threats. Their fate stood in stark contrast with the rise of Japan and the dominance of medium-sized states in Europe. 


\section{Discussion And Extensions}

We stress that we do not purport to offer a universal account of state centralization or fragmentation. Clearly, there are episodes of state centralization that have occurred in the absence of geopolitical threats, in which case our model would not be applicable. Nevertheless, the mechanisms that we highlight are not specific to China and Japan but apply more broadly to other parts of the world and contains generalizable insights for understanding the process of state-building.

For one, the unification of Anglo-Saxon England and the fragmentation of the Carolingian empire in the ninth century provides an interesting historical parallel to the nineteenth-century divergence between China and Japan. Viking raids from the north (a severe, one sided threat) provided the impetus that enabled the West Saxon unification of England (a small, initially politically fragmented territory). However, the same factor, in conjunction with Magyar invasions from Eastern Europe and Muslim invasions from North Africa (i.e., multi-sided threats), contributed to the fragmentation of continental Western Europe (a large territory) as the Carolingian rulers lacked the administrative capacity to implement centralizing reforms in their large empire and had to allow local aristocrats to take over regalian rights, raise armies, build fortifications, acquire mints and mines, and become residual claimants on local resources to defend the frontiers. In Appendix A, we provide a detailed discussion of Anglo-Saxon England and the Carolingian empire. We also discuss Muscovy Russia of the fifteenth century, which provided an example of a large territory unifying in response to a one-directional geopolitical threat.

In the remaining of this section, we address a few possible criticisms of our framework.

First, the model assumes that authorities do not compete for territorial gains. We remove this assumption in the general model in Appendix B. Without this assumption, authorities need to defend themselves not only against foreign threats, but against each other too. This would strengthen the model's implications - for example, it would generate a larger impetus for Japan to move from decentralization to centralization in the mid-nineteenth century, since political decentralization now leads to more resource competition than previously assumed. It would also help to explain why China's political decentralization in the nineteenth century was partial and incomplete, and why the imperial court hesitated over reform and allowing provincial authorities to drive China's modernization.

Second, our conclusion that a large territory requires further state building before it can be ready for radical socioeconomic change is not driven by the assumption of $S \leq 2$. To see this, suppose authorities $l$ and $r$ can devolve power to new authorities by voluntarily giving up land (i.e., $S>2$ is permissible). Now, for the entire territory to have sufficient state capacity so that 


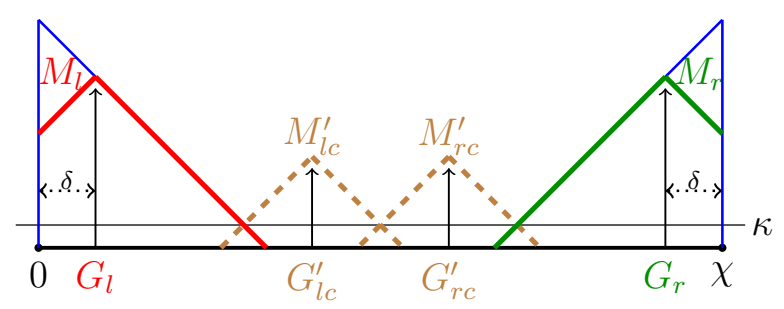

Figure 15: The desire to reform pushes a large territory toward further decentralization with the setting up of two new authorities, $l c$ and $r c$, to administer its inner segment.

reform can be pursued, $l$ and $r$ could (a) increase their respective investments (as in Figure 13), or (b) allow new authorities to be set up (as in Figure 15) - the new authorities will still have to build state capacity in the previously under-administered inner segment to a level above $\kappa$.

Third, in the model once an authority builds sufficient state capacity, the success of reform is guaranteed. This essentially assumes that authorities know how to reform. In reality, reform is a risky business and while one could learn from others, there is no guarantee that what works in one country would work in another. In our case study, it is plausible that because Japan was comparable in size to the Western European states, the cost for it to adopt Western institutions and copy Western practices were lower and its chance of success higher. China was a completely different beast. No other country was remotely comparable in size - the United States had a population of 23 million in 1850, Jiangsu - one of the eighteenth provinces in China properalone had 44 million people. It is not obvious that Western institutions and practices, based on organizational principles tried and tested in small and medium-sized polities, could be successfully transplanted into China without distorting their intended purposes. Indeed, sociologists have argued that important similarities between Japanese and European feudalism had facilitated Japan's embrace of capitalism and Western political and social institutions (Anderson, 1974; Umesao, 2003). Taking this factor into account would again strengthen our conclusion.

Fourth, it may seem like a shortcoming of our analysis that we take the size of a territory as exogenous. In fact, this is not a bad approximation in the case of China and Japan. Japan is an island archipelago, while China proper is traditionally bounded by major geographical barriers: the Gobi desert in the north, the Himalayas in the West, the dense tropical rainforest in the south, and the Pacific Ocean in the east. ${ }^{18}$

Fifth, for analytical convenience we have abstracted from the composition of the political leadership. In the case of Japan, Aoki (2014) argues that the common samurai-administrator

\footnotetext{
${ }^{18}$ While the Qing empire expanded into present-day Xinjiang, Mongolia, and Tibet, these lands were economically unproductive. In 1820, China proper accounted for 98\% of the Qing empire's population (Sng and Moriguchi, 2014). Conceptually, the new lands can be considered as "barriers" that help define the territorial limits of China proper instead of its natural and undifferentiated extensions.
} 
background of ruling class helped smooth the Tokugawa-Meiji transition. Meanwhile, mistrust between the Manchu imperial court and the Han Chinese majority grew over the course of the nineteenth century as the traditional political order unraveled (Fairbank, 1992; Rowe, 2009). It is not clear if racial division contributed meaningfully to the disagreement between the late-Qing reformists and ultraconservatives, since the two camps were not split along racial lines. But if it did, it would have deepened the dilemma that the Chinese state faced over decentralization and reform. Our model points to the greater salience of reform in Japan, which was in the common interests of its ruling coalition. This is in keeping with the historical record. For example, while there were initial conflicts within the Tokugawa Shogunate in the $1850 \mathrm{~s}$ - as reflected by the Ansei Purge in which opponents of the opening up to western trade were removed from official positions - by the 1860s, a consensus emerged among the leaders in all camps about the need to implement radical reforms (Jansen, 1961). The subsequent Satsuma Rebellion does not contradict but instead validates our argument: the participants of the rebellion were dislocated samurai whose interests were hurt in the reform process and the rebellion was decisively suppressed because the state in Meiji Japan had sufficient capacity to do so.

Sixth, in the context of nineteenth-century China and Japan, one may assume in the model that the new threats observed in China are more severe than in Japan to reflect the perception that China bore the brunt of Western imperialism due to its closer proximity to Europe and because the size of its market made it a more attractive target (Rowe, 2009). This would not affect our analysis. As one could deduce from Figure 14 of the numerical example, we would reach the same conclusions in Section 3.3 if we assume that $\Lambda_{l, \text { China }}>\Lambda_{l, \text { Japan }}$ and $\Lambda_{r, \text { China }}>\Lambda_{r, \text { Japan }}$.

Finally, it is important to note that while our model can explain the choices and attitudes of the political leaders in China and Japan at this critical juncture, it does not predict the outcomes of the choices made. For example, the model predicts that the emergence of severe geopolitical threats in the nineteenth century would push Japan decisively toward political centralization, but it has no explanatory power on whether the Shogunate or the anti-Shogunate coalition would emerge victorious. Likewise, in our model political leaders are uncertain about the degree of success of reform when deciding whether to implement it. We do not assume that the leaders in Japan knew ex-ante that reform would reap huge rewards. Indeed, our model suggests that uncertainty was one of the factors that contributed to the Chinese leaders' initial ambivalence toward reform. 


\section{COnClusion}

Recent research suggests that the existence of a centralized state can play a crucial role in laying the foundation for sustained economic growth (Acemoglu and Robinson, 2012). In this paper we study how geopolitical threats can lead to either state centralization or state fragmentation. We build a model in which the existence of multi-sided geopolitical threats provides the incentives for rulers of compact polities to centralize political institutions and invest in state capacity, but can lead rulers of larger territories to devolve political power and underinvest in state capacity.

We apply this model to study an important historical episode: the creation of a unified state in Japan and the corresponding failure of China to modernize during the second half of the nineteenth century. Our analysis sheds new light on why China, which had been centralized for much of its history, experienced disintegration upon the arrival of Western powers, and why Japan, which had been politically fragmented for centuries, became unified and implemented comprehensive reforms during the same period. In contrast to traditional accounts, our analysis does not rely on exogenous differences in cultural attitudes toward reform or in the competence of policymakers in China and Japan.

Our analysis provides new insights into the institutional preconditions for sustained economic growth. The spread of innovation and economic growth that followed the Industrial Revolution offered many countries the possibility to import new technologies, attract capital and investment, and to experience economic development, but only those countries with the appropriate political institutions were able to realize it. China and Japan offer an important case study that sheds new light on the political preconditions for building a state capable of achieving modern economic growth.

\section{REFERENCES}

Abels, R. (1998). Alfred the Great. Harlow, UK: Longman.

Acemoglu, D., C. Garcia-Jimeno, and J. A. Robinson (2015). State capacity and economic development: A network approach. American Economic Review 105(8), 2364-2409.

Acemoglu, D., S. Johnson, and J. Robinson (2005). The rise of Europe: Atlantic trade, institutional change, and economic growth. American Economic Review 95(3), 546-579.

Acemoglu, D. and J. A. Robinson (2000). Political losers as a barrier to economic development. American Economic Review 90(2), 126-130.

Acemoglu, D. and J. A. Robinson (2001). A theory of political transitions. American Economic Review 91(4), 938-963.

Acemoglu, D. and J. A. Robinson (2012). Why Nations Fail. New York: Crown Business. 
Alesina, A. and E. Spolaore (2003). The Size of Nations. Cambridge, MA: MIT Press.

Anderson, P. (1974). Lineages of the Absolutist State. London: Verso.

Aoki, K. (1971). Hyakushoo ikki sogo nenpyo [A chronology of peasant protests]. Tokyo: San'ichi Shobo. Aoki, M. (2014). Three-person game of institutional resilience versus transition. Mimeo.

Arias, L. M. (2013). Building Fiscal Capacity in Colonial Mexico: From Fragmentation to Centralization. Journal of Economic History 73(03), 662-693.

Baark, E. (1997). Lightning wires: the telegraph and China's technological modernization, 1860-1890. Westport, CT: Greenwood Press.

Barfield, T. (1989). The Perilous Frontier: Nomadic Empires and China. Oxford: Basil Blackwell.

Beasley, W. (1973). The modern history of Japan. London: Weidenfeld and Nicolson.

Beasley, W. (2000). The rise of modern Japan. New York: St. Martin's Press. 3rd edition.

Besley, T. and T. Persson (2011). Pillars of Prosperity. Princeton: Princeton University Press.

Campbell, J. (2000). The Anglo-Saxon State. London: Hambledon and London.

Chaney, E. and L. Blaydes (2013). The feudal revolution and Europe's rise: Political divergence of the Christian and Muslim worlds before 1500 CE. American Political Science Review 107(1), 16-34.

CHGIS (2007). Version 4. Harvard Yenching Institute, Cambridge, MA.

Chu, S. and K.-C. Liu (Eds.) (1994). Li Hung-chang and China's early modernization. Armonk, NY: M.E. Sharpe.

Coşgel, M. M., T. J. Miceli, and J. Rubin (2012). The political economy of mass printing: Legitimacy and technological change in the Ottoman empire. Journal of Comparative Economics 40(3), 357-371.

Dhoudt, J. (1948). Études sur la naissance des principautés territoriales en France (IXe-Xe siècle). Bruges: De Tempel.

Dincecco, M. (2009). Fiscal centralization, limited government, and public revenues in Europe, 1650-1913. Journal of Economic History 69(1), 48-103.

Dincecco, M. (2010). Fragmented authority from ancien régime to modernity: a quantitative analysis. Journal of Institutional Economics 6(03), 305-328.

Dincecco, M. (2015). The Rise of Effective States in Europe. Journal of Economic History 75(03), 901-918.

Dincecco, M. and G. Katz (2014). State capacity and long-run economic performance. Economic Journal Forthcoming.

Doner, R., B. Ritchie, and D. Slater (2005). Systemic vulnerability and the origins of developmental states: Northeast and Southeast Asia in comparative perspective. International Organization 59(2), $327-361$.

Duke, B. (2009). The history of modern Japanese education: constructing the national school system,18721890. New Brunswick, NJ: Rutgers University Press.

Fairbank, J. (1992). China: a new history. Cambridge, MA: Belknap.

Fairbank, J. and E. Reischauer (1989). China: tradition and transformation. Boston: Houghton Mifflin. Fennell, J. (1983). The Crisis of Medieval Russia 1200-1304. Longman.

Feuerwerker, A. (1980). Economic trends in the late Ch'ing empire, 1870-1911. In J. Fairbank and K.-C. 
Liu (Eds.), Cambridge History of China, vol. 11, pp. 1-69. Cambridge: Cambridge University Press. Fukuyama, F. (2011). The Origins of Political Order: From Prehuman Times to the French Revolution. New York: Farrar, Straus and Giroux.

Gennaioli, N. and H.-J. Voth (2015). State capacity and military conflict. Review of Economic Studies 82(4), 1409-1448.

Grossman, S. and O. Hart (1986). The costs and benefits of ownership: a theory of vertical and lateral integration. Journal of Political Economy 94(4), 691-719.

Haggard, S., D. Kang, and C.-I. Moon (1997). Japanese colonialism and Korean development: A critique. World Development 25(6), $867-881$.

Hao, Y.-P. and E.-M. Wang (1980). Changing Chinese views of Western relations. In J. Fairbank and K.-C. Liu (Eds.), Cambridge History of China, vol. 11, pp. 142-201. Cambridge: Cambridge University Press.

Hart, R. (1975). The I.G. in Peking: letters of Robert Hart, Chinese Maritime Customs, 1868-190\%. Cambridge, MA: Belknap.

He, W. (2013). Paths toward the modern fiscal state: England, Japan, and China. Cambridge, MA: Harvard University Press.

Hoffman, P. (2015a, 6). What do states do? Politics and economic history. Journal of Economic History 75, 303-332.

Hoffman, P. (2015b). Why Did Europe Conquer the World? Princeton: Princeton University Press.

Iyigun, M. and J. Rubin (2017). The ideological roots of institutional change. Mimeo.

Jansen, M. (1961). Sakamoto Ryoma and the Meiji Restoration. New York: Columbia University Press. Jansen, M. (2000). The Making of Modern Japan. Cambridge, MA: Belknap.

Jin, S. and W. Xu (Eds.) (1986). Zhongguo tielu fazhan shi (The development history of the Chinese railroads). Beijing: China Railway Publishing House.

John, E. (1982). The age of Edgar. In J. Campbell (Ed.), The Anglo-Saxons, London, pp. 160-191. Penguin.

Johnson, N. and M. Koyama (2014). Tax farming and the origins of state capacity in England and France. Explorations in Economic History 51(1), 1-20.

Johnson, N. D. and M. Koyama (2017). States and economic growth: Capacity and constraints. Explorations in Economic History 64, 1-20.

Jones, S. R. H. (1993). Transaction costs, institutional change, and the emergence of a market economy in later Anglo-Saxon England. Economic History Review 46(4), 658-678.

Khodarkovsky, M. (2002). Russia's Steppe Frontier. Indiana University Press.

Ko, C. Y., M. Koyama, and T.-H. Sng (2014). Unified China; Divided Europe. International Economic Review. Forthcoming.

Kuhn, P. (1980). Rebellion and its enemies in late imperial China: Militarization and social structure, 1796-1864. Cambridge, MA: Harvard University Press.

Kuhn, P. A. (2002). Origins of the Modern Chinese State. Stanford: Stanford University Press.

$\mathrm{Li}, \mathrm{W}$. (2008). The interaction between ethnic relations and state power: a structural impediment to the 
industrialization of China, 1850-1911. Dissertation, Georgia State University.

Lipset, S. M. (1963). Political Man: The Social Bases of Politics. New York: Anchor Books.

Liu, K.-C. and R. Smith (1980). The military challenge: The north-west and the coast. In J. Fairbank and K.-C. Liu (Eds.), Cambridge History of China, vol. 11, pp. 202-73. Cambridge: Cambridge University Press.

Loyn, H. (1984). The Governance of Anglo-Saxon England 500-108\%. Stanford: Stanford University Press.

Ma, D. (2004). Why Japan, not China, was the first to develop in East Asia: lessons from sericulture, 1850-1937. Economic Development and Cultural Change 52(2), 369-394.

Ma, D. and J. Rubin (2017). The paradox of power: Understanding fiscal change in imperial China and absolutist regimes. Mimeo.

Mao, Z. (1990). Mao Zedong zao qi wen gao 1912.6-1920.11 [Mao Zedong's early manuscripts]. Changsha: Hunan Press. Edited by Xu Rihui.

Michalopoulos, S. and E. Papaioannou (2014). National institutions and subnational development in Africa. Quarterly Journal of Economics 129(1), 151-213.

Mokyr, J. (1990). The Lever of Riches. Oxford: Oxford University Press.

Morrissey, R. (1997). Charlemagne \& France. Notre Dame: University of Notre Dame Press. Translated by Catherine Tihanyi.

Nakabayashi, M. (2012). Rise of the Japanese fiscal state. In B. Yun-Casalilla, P. O'Brien, and F. Comin Comin (Eds.), The Rise of Fiscal States: A Global History, 1500-1914, pp. 378-409. Cambridge: Cambridge University Press.

North, D. C. (1981). Structure and Change in Economic History. New York: W. W. Norton.

North, D. C. (1990). Institutions, Institutional Change, and Economic Performance. Cambridge: Cambridge University Press.

North, D. C., J. J. Wallis, and B. R. Weingast (2009). Violence and Social Orders: a conceptual framework for interpreting recorded human history. Cambridge: Cambridge University Press.

North, D. C. and B. Weingast (1989). Constitutions and commitment: the evolution of institutions governing public choice in seventeenth century England. Journal of Economic History 49, 803-32.

Nussli, C. (2011). URL: http://www.euratlas.com/about.html.

Olson, M. (1963). Rapid growth as a destabilizing force. Journal of Economic History 23(4), 529-552.

Oman, C. (1924). A History of the Art of War in the Middle Ages, Volume One: 1278-1485. London: Greenhill.

Paik, C. and J. Vechbanyongratana (2017, March). Legacy of colonial expansion on centralization and development: Evidence from Thailand. Mimeo.

Paine, S. (2003). The Sino-Japanese War of 1894-1895. Cambridge: Cambridge University Press.

Perrie, M. (Ed.) (2006). Cambridge History of Russia Volume 1. From Early Rus' to 1689. Cambridge: Cambridge University Press.

Pong, D. (1987). Keeping the Foochow navy yard afloat: Government finance and China's early modern defence industry, 1866-75. Modern Asian Studies 21(1), 121-152. 
Ravina, M. (1999). Land and Lordship in Early Modern Japan. Stanford: Stanford University Press.

Remick, E. (2004). Building local states: China during the Republican and post-Mao eras. Cambridge,

MA: Harvard University Asia Center.

Reuter, T. (1990). The end of Carolingian military expansion. In P. Goodman and R. Collins (Eds.), Charlemagne's Heirs: New Perspectives on the Reign of Louis the Pious (814-840), Oxford, pp. 391-408. Oxford University Press.

Rosenthal, J.-L. and R. B. Wong (2011). Before and beyond divergence: the politics of economic change in China and Europe. Cambridge, MA: Harvard University Press.

Rowe, W. (2009). China's Last Empire: the Great Qing. Cambridge, MA: Harvard University Press.

Shi, Z. (2009). Revenue, expenditure and inventory statistics of the Qing Board of Revenue Silver

Treasury [Qingdai hubu yinku shouzhi he kucun tongji]. Fuzhou: Fujian People's Publishing House.

Shi, Z. and Y. Xu (2008). Wan qing caizheng: 1851-1894 [Finance of the Late Qing Dynasty]. Shanghai:

Shanghai University of Finance and Economics.

Slater, D. (2010). Ordering Power. Cambridge: Cambridge University Press.

Sng, T.-H. (2014). Size and dynastic decline: The principal-agent problem in late imperial China 1700-1850. Explorations in Economic History 54(0), 107-127.

Sng, T.-H. and C. Moriguchi (2014). Asia's little divergence: State capacity in China and Japan before 1850. Journal of Economic Growth 19(4), 439-470.

Spruyt, H. (1994). The Sovereign State and Its Competitors. Princeton: Princeton University Press.

Strayer, J. (1970). On the Medieval Origins of the Modern State. Princeton, New Jersey: Princeton University Press.

Sunderland, W. (2004). Taming the Wild Field: Colonization and Empire on the Russia Steppe. Ithaca:

Cornell University Press.

Tanaka, S. (2004). New times in modern Japan. Princeton: Princeton University Press.

Tang, J. (2013). Railroad expansion and entrepreneurship: evidence from Meiji Japan. CEH Discussion

Papers No. 2013-01.

Tilly, C. (1990). Coercion, Capital, and European States, AD 990-1990. Oxford: Blackwell.

Totman, C. (1993). Early Modern Japan. Berkeley: University of California Press.

Turchin, P. (2009). A theory for formation of large empires. Journal of Global History 4, 191-217.

Umesao, T. (2003). An ecological view of history: Japanese civilization in the world context. Melbourne:

Trans Pacific.

Vu, T. (2010). Paths to Development in Asia. Cambridge: Cambridge University Press.

Wang, H.-C. (2015). Merchants, mandarins, and the railway: Institution failure and the Wusong Railway,

1874-1877. International Journal of Asian Studies 12, 31-53.

Weber, M. (1968). Economy and Society. New York: Bedminster.

Wehrle, E. (1966). Britain, China, and the Anti-Missionary Riots 1891-1900. London: Oxford University Press.

Wormald, P. (1982). The ninth century. In J. Campbell (Ed.), The Anglo-Saxons, London, pp. 132-160. Penguin. 
Wright, M. C. (1957). The last stand of Chinese conservatism: the Tung-Chih restoration, 1862-18\%4. Stanford: Stanford University Press.

Yorke, B. (1990). Kings and the Kingdoms of Early Anglo-Saxon England. London: Routledge. 


\section{A Appendix: External Validity}

If our framework can provide a valid account of the divergence in state development in East Asia after 1850, it should also cast light on other similar examples of state formation. Here we apply our model to three other cases to provide some evidence for the generalizability and external validity of our framework.

\section{A.1 Anglo-Saxon England}

Anglo-Saxon England provides an example of centralization in small territory facing a severe one-sided external threat. In response to Viking invasions from the north, the kingdom of Wessex was able to unify much of England and to build a precociously centralized state.

Early Anglo-Saxon England was politically fragmented. Between 650 and 800 AD its political configuration is traditionally referred to as the Heptarchy in reference to the seven main kingdoms that comprised it, though in practice the number of competing kingdom varied over time. The main kingdoms were Kent, Wessex, Mercia, Essex, Sussex, East Anglia, and Northumbria. Within the Heptarchy, a particular kingdom might obtain temporary predominance as, for instance, Northumbria did in the seventh century and Mercia did in the eighth century under the overlordship of Offa (r. 757-796). Nevertheless, no ruler came close to unifying England. ${ }^{19}$

Prior to 850, the threats facing these Anglo-Saxon kingdoms were small. Warfare was endemic but small scale. Wessex and Mercia faced sporadic border conflicts with the remnants of the British kingdoms that inhabited Wales and Cornwall, while Northumberland faced raids and periodic war with the kingdom of Strathclyde and from the Picts and Scots. But these threats did not threaten the stability of the Anglo-Saxon kingdoms.

Like the Black Ships that confronted Tokugawa Japan a millennium later, the external threat posed by the Vikings after 850 was both unexpected and qualitatively different in magnitude. They sought the long-term conquest of parts of the British isles and rapidly overran the kingdoms of Northumbria, East Anglia, and Mercia. ${ }^{20}$ The kings of Northumbria and East Anglia were killed, perhaps as sacrifices to the pagan deity Woden (Wormald, 1982, 148). In the language of our model, the Viking threat that emerged in 850 s was a severe one-sided threat.

The kingdom of Wessex, however, survived because it was among the larger and more powerful

\footnotetext{
${ }^{19}$ During the Mercian period, historians detect a tendency toward political unification. For example, Offa fought numerous conflicts with Kent and claimed the kingship of Kent between 772-774 but for most of this period the rulers of Kent were able to assert their independence (Yorke, 1990, 31).

${ }^{20}$ The size and scale of the Viking raids has been the subject of controversy among historians. See discussion in Wormald (1982, 132-152). While revisionist historians sought to scale back tradition accounts of the devastation wrought by the Vikings, the modern consensus agrees that the Viking attacks of the second part of the ninth century represented major invasions involving armies numbering in the thousands.
} 

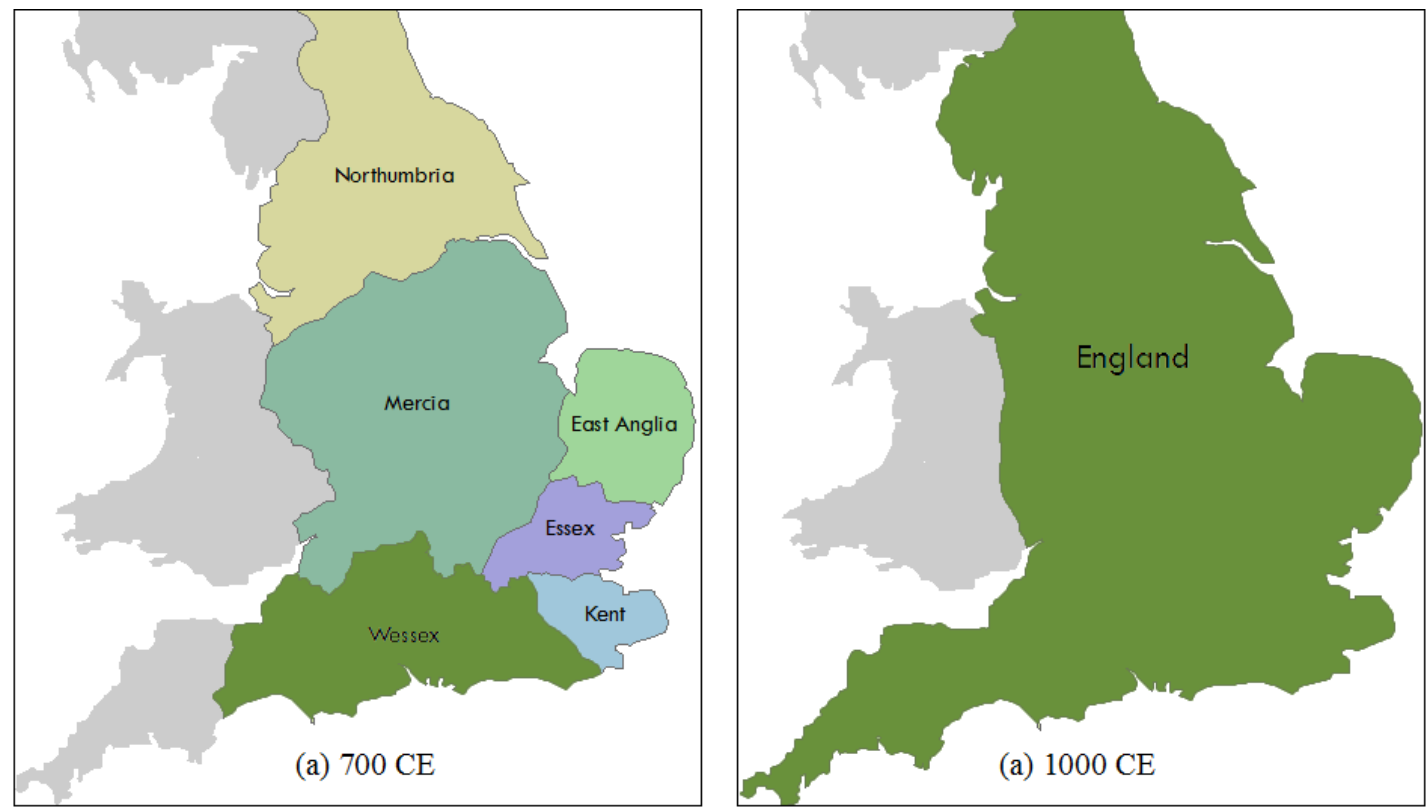

Figure 16: The Anglo-Saxon Heptarchy. Between 850 and 1000, the kings of Wessex created a unified kingdom of England. Note boundaries were in flux during the seventh and eighth centuries. Adapted from Nussli (2011).

Anglo-Saxon kingdoms and because geographical location protected it from the first brunt of the Viking invasion. Alfred the Great (r. 871-899) halted the invasion by the Viking "grand army" in 878 and used the breathing space this bought him to mobilize the resources of the unconquered parts of his territory and to raise an army strong enough to roll back the Viking advance. In 886, Alfred captured London. This marks the beginning of the West Saxon unification of England and "the gradual and halting emergence of a new kingdom that extended beyond the territorial or tribal confines of the ancient kingdoms of Wessex, Kent, or Mercia" (Abels, 1998, 24-25). ${ }^{21}$

Alfred first unified the rival kingdoms of Wessex and Mercia and this union became the foundation for this new English kingdom (Loyn, 1984, 8). Consistent with our model, only a larger kingdom than Wessex was capable of providing the level of defense now needed to defeat the Viking threat. Alfred combined the Anglo-Saxon kingdoms to increase the amount of resources he could collect for the purpose of defense.

However, he did more than this. Historians attribute Alfred's success to his ability to increase state capacity: the reign of Alfred the Great saw the establishment of a "large standing army and navy together with a public works programme of unparalleled magnitude" (Jones, 1993, 669). Alfred established a system of fortifications known as burghs that provided a point of refuge

\footnotetext{
${ }^{21}$ As one historian notes "[i]f one needs a date for the beginning of an English kingdom this is as good as any" (John, 1982, 160).
} 
for the population from attack by Viking raiders. These fortifications were bureaucratically planned and documented. Wormald notes: "the burghal system involved the deployment of colossal manpower resources ... There is no more impressive evidence before Domesday Book of the capacities of Anglo-Saxon government" (Wormald, 1982, 154). With some caveats we can view this as a program of "modernization" akin to that undertaken by peripheral societies in the nineteenth and twentieth centuries.

The unification of Anglo-Saxon England is a classic case of state formation under the threat of invasion. Subsequent kings of Wessex would unify the entirety of England (though they would call themselves rulers of the West Saxons, Mercians, or Angles as regional identities remained important). ${ }^{22}$ In the face of a continued threat of new Viking invasions, the Anglo-Saxon kings' policy of conquest and unification was accompanied by state building and investment in fiscal and legal capacity. Tenth-century Anglo-Saxon kings were legislators. They sought to limit violence, for example by trying to prohibit feuding, and to impose common laws, and created "a crude but powerful bureaucracy" (John, 1982, 176). Historians argue that this precocious unification helped put England on the path toward early centralization, a characteristic which numerous scholars have pointed to in accounting for the subsequent success the English state had in building fiscal capacity (e.g., Dincecco, 2010; Johnson and Koyama, 2014). ${ }^{23}$ Certainly, at no point in its subsequent history was England ever divided into separate realms again.

\section{A.2 The Fragmentation of the Carolingian Empire}

Anglo-Saxon England centralized in response to the threat posed by the Vikings. Across the channel, however, the empire of Charlemagne fragmented under the pressure of external threats from Vikings in the north, Slavs and Magyars in the East, and Muslims from the south.

The Carolingian empire was established through the conquests of Charlemagne (r. 768-814) who ruled over France, the Low Countries, much of Italy and Germany, and large parts of central Europe. On Charlemagne's death, the empire was passed on to his son Louis the Pious (r. 814-840) who spent his reign defending the frontiers from a variety of threats and facing down internal revolts. As one historian notes, there was fighting on a number of fronts:

\footnotetext{
${ }^{22}$ Eadred (r. 946-955), for instance, called himself "king, emperor of the Anglo-Saxons and Northumbrians, governor of the pagans, defender of the Britons" (John, 1982, 168).

${ }^{23}$ As Campbell (2000) notes, "Late Anglo-Saxon England was a nation state. It was an entity with an effective central authority, uniformly organised institutions, a national language, a national church, defined frontiers, and, above all, a strong sense of national identity" (10). "England was by then [1066] a nation-state. It is highly improbable that any European rulers enjoyed closely organised authority over so wide an area as did its kings. The dominions of the German King Henry IV were far more extensive, but the extent of his authority varied from area to area; his government was by no means uniformly integrated; and he did not rule a state in the sense that Edward the Confessor did. There is no question of there having been anything comparable to the English state in France, Spain or Italy" (31-32).
} 
in the south-west against the Muslims of Spain and the Basques; in the north-west against the Bretons; in the north-east against the Danes and their Slav allies; in the south-east against the Serbs and the Bulgars; and in Italy against the Byzantines and Beneventans. In addition there were invasion scares in the 800s on the north French coast, real invasions in southern Italy and Frisia, and skirmishes in the Mediterranean Islands (Reuter, 1990, 391).

Viking raids began during the reign of Charlemagne but increased after his death. Louis the Pious's reign was also beset by civil wars, which reveal the pressure to decentralize military and political authority in response to local invasion threats (Morrissey, 1997). Charles Oman in surveying the decline of the Carolingian empire notes that 'three or four compact national kingdoms would be better able to cope with the Vikings than the vast but somewhat unwieldy empire of Charles the Great' (Oman, 1924, 95).

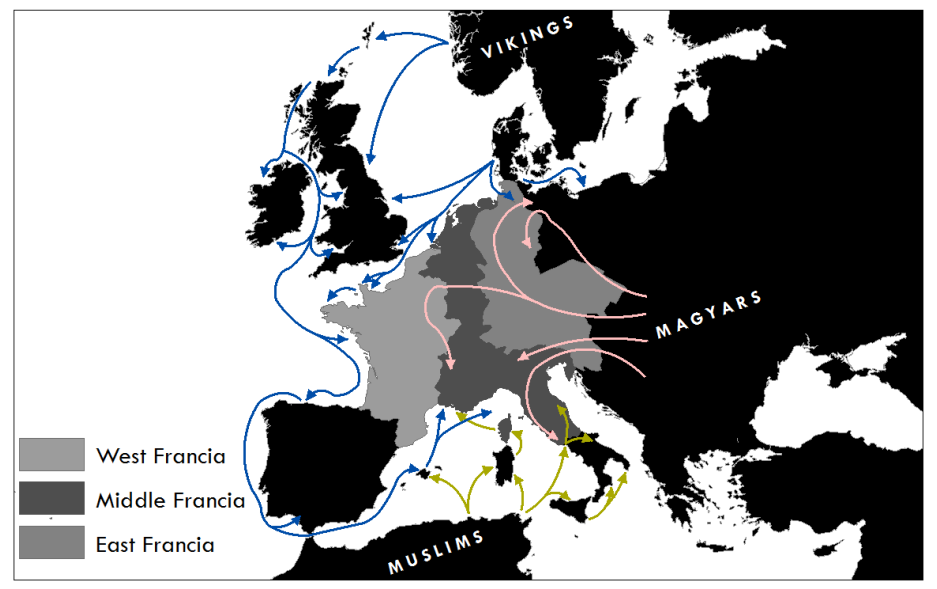

Figure 17: Viking, Magyar, and Muslim Invasions of Western Europe in the Ninth and Tenth Centuries; The Carolingian Empire after the partition of AD 843.

Civil war led to the division of the empire in 843 into West Francia, East Francia, and Middle Francia at the Treaty of Verdun (Figure 17). The empire was briefly reunited by Charles the Fat (r. 881-888) but his reign could not halt the process of internal decentralization as the power of the king weakened in relation to local elites. Positions like the counts which were originally royal appointments were converted into hereditary ones as these local power holders raised armies to defend against Viking or Muslim raiders, setting the stage for the 'feudal revolution' that took place after 900 (Strayer, 1970; Chaney and Blaydes, 2013).

In summary, historians and political scientists agree that the fragmentation of central power was at least partly in response to the external threats that the empire faced (Dhoudt, 1948; Spruyt, 
1994). ${ }^{24}$ Our model helps to explain why the response to the Viking threat in Anglo-Saxon England was state consolidation and centralization whereas the Carolingian empire weakened into response to Viking raids. First, Wessex was a small and compact polity and it was possible for Alfred the Great and his successors to build the core of a coherent state within the territories of Wessex before subduing the rest of Anglo-Saxon England. In contrast, the Carolingian empire was extremely large and cumbersome. Carolingian rulers lacked the administrative capacity to fully implement centralizing reforms. Second, the threats facing the Carolingian rulers came from multiple directions: it was impossible for the emperor to be present in, for example, both Saxony and the Basque region in a single campaigning season. Political decentralization was therefore the natural response to this multi-dimensional threat: local aristocrats took over regalian rights, raising armies, building fortifications, acquiring mints and mines, and becoming residual claimants on local resources.

\section{A.3 Muscovy Russia}

We now consider the example of a large territory unifying in response to a one-directional geopolitical threat: the rise of Muscovy and the foundation of the Russian empire.

Muscovy was not one of the principalities that formed the Kevian Rus', the first state in Russia. Under Yaroslav I (r. 1019-1054) and other early rulers, the Kievan Rus' was a loose federation of principalities that owed fealty to the ruler of Kiev. Figure 18a depicts the borders of the various principalities that made up the Kievan Rus' in the mid-1200s.

By the end of the twelfth century, the Kievan state was divided into roughly twelve different principalities. The most important of these included the Republic of Novgorod, the Grand Duchy of Vladimir, and the Kingdom of Galicia-Volhynia. The Kievan states comprised agriculturalists in the south who practiced slash and burning agriculture and hunters, trappers, and woodsmen in the north. There was continuous low-level conflict with the nomads of the steppe, notably the Pechenegs, Torki (Oguz), and Polovtsy (Qipchap, Cumans) who raided the settled lands sporadically (Sunderland, 2004, 12). However, the conflict did not pose a threat to the existence of the different Kievan regimes.

This changed dramatically with the Mongol invasions of the thirteenth century. As with the Viking invasions of England, this was a non-trivial exogenous shock. The Russian states were vulnerable because they were divided. As one historian notes "it was not so much military unpreparedness and inefficiency that enfeebled the Russians as lack of unity between territories in the north, the south and the south-west. There was no suzerain prince who had effective

\footnotetext{
${ }^{24}$ As Spruyt observes, 'the breakup of central authority coincided with the increasing raids by Magyars, Saracens, and Vikings' (Spruyt, 1994, 37).
} 


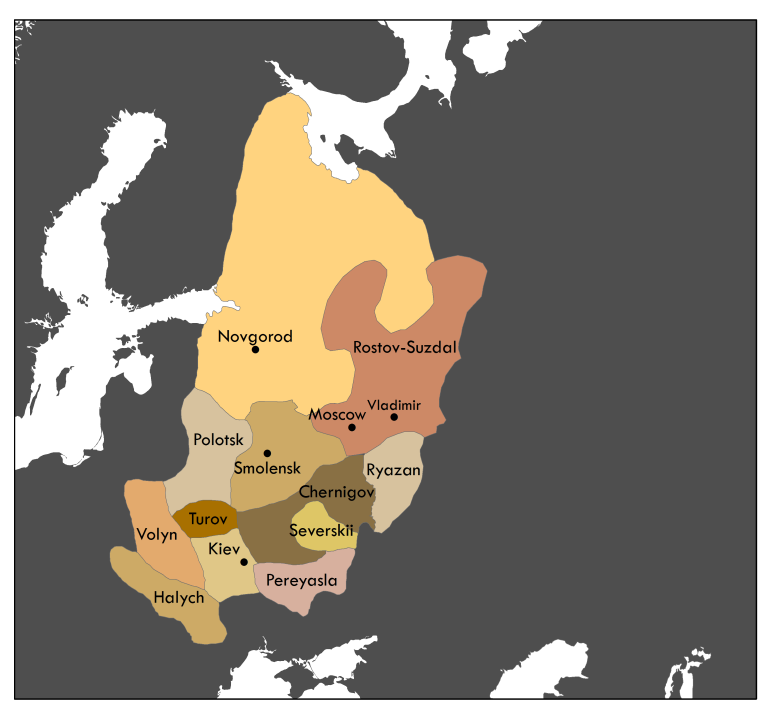

(a) Rus' Principalities, 1246

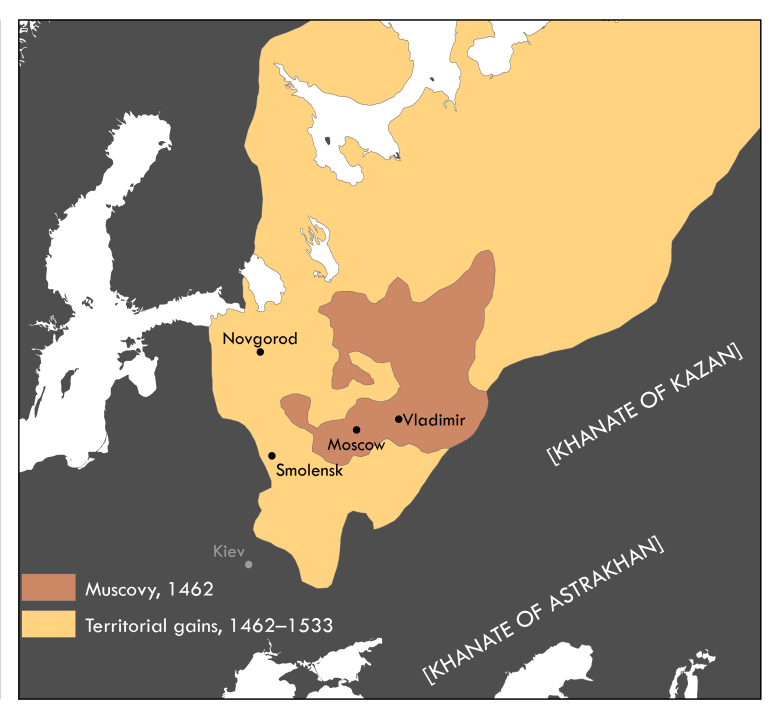

(b) Expansion of Muscovy, 1462-1533

Figure 18: The Unification of the Russian World. Adapted from Perrie (2006).

control over all Russian lands" (Fennell, 1983, 86). Contemporary chroniclers portray these invasions in catastrophic terms listing city after city that was sacked. Modern historians are unable to estimate overall population losses but they agree that the devastation must have been tremendous. Russia remained under Mongol domination for the subsequent two centuries. It was only gradually that a new principality, Muscovy, was able to consolidate power in the lands north of the old Kievan state.

In the late fifteenth century, Ivan III (r. 1462-1505) absorbed the other Russian principalities and overthrew the power of the Golden Horde, thereby laying the foundations for the Russian empire. Muscovy succeeded in repelling nomadic invasions from the East by investing massively in frontier defenses. As in Anglo-Saxon England, the rulers of Muscovy invested in "palisades and earthworks between stands of forest to 'cut-off' nomadic raiding routes" (Sunderland, 2004, 24). Khodarkovsky $(2002,221)$ notes that because of Muscovy's long eastern border (Figure 18b),

[its] frontiers remained "soft targets", vulnerable to large-scale nomadic invasion and impossible to defend against small-scale lightning raids. The lessons of the Mongol conquest and its devastating impact upon the entire Eurasian continent were clear: only a strong state with a centralized government capable and willing to devote significant resources to the defense of the steppe frontier could prevent similar disasters.

Yet by the late sixteenth century, the centralized empire that the rulers of Muscovy built was facing threats from the west as well as the east. Consistent with our theory, these two-sided 
threats almost led to its breakup during the Time of Troubles (1598-1613). However, the new Romanov dynasty was able to make peace in the west so as to focus on (and eventually subdue) the threat from the steppe.

These examples could be expanded upon. In particular, history offers many examples of geographically compact states such as Macedon, the Dutch Republic and Prussia building strong states in response to foreign threats. However, it is important to emphasize that we do not claim that the emergence of a strong external threat would always lead to centralization. If the threat is too strong, it will overrun a decentralized territory without giving it the opportunity to unify. Nevertheless, even in these cases, the systematic tendencies we identify in our model may still be detected. For example, the Roman invasion of Gaul in the 50s BCE was so strong that it overwhelmed resistance and led to the incorporation of Gaul into the Empire. However, the force of the initial invasion did cause the fragmented tribes of Gaul to unify into a federation under Vercingetorix in order to resist. In this case, the tendencies identified by our theory were present but the result was a Roman victory instead of a unified Gaul. 


\section{B Appendix: General Model}

In Section 3, we provide a stylized model to highlight the key mechanisms and results. Below, we lay down a general model that (1) does not assume specific parametric forms, and (2) endogenizes border formation, to show that the findings of the stylized model are robust to a relaxation of its assumptions.

The general setup of the model is unchanged. As before, we model a territory as a line $[0, \chi]$ with $\chi$ individuals uniformly distributed along this line. Each individual is endowed with income $y$.

The territory faces threats from outside. An external threat of magnitude $\Lambda$, if undeterred, causes gross damage is $\max \{\lambda(\Lambda, t), 0\}$ at a point $t$ distance away from the frontier, where $\lambda_{1}>0$, $\lambda_{2}<0$, and $\alpha>0$ is a scaling constant. Moreover, threats may emanate either from one frontier (at $x=0$ only, without loss of generality) or from both frontiers. Whether they are one-sided or two-sided, and the value of $\Lambda$, depends on the continent's geographical environment, which is exogenously determined.

The territory is divided into $S \in\{1,2\}$ connected, mutually exclusive intervals, each administered by a regime (authority). When $S=1$ (political centralization), one regime $c$, rules the entire continent. When $S=2$ (political fragmentation), two regimes, $l$ and $r$, coexist. Regime $l$ is on the left of regime $r$. We focus on the symmetric equilibrium for tractability.

Regime $i$ may invest in state capacity, and the cost of doing so is convex. For regime $i \in\{c, l, r\}$ to invest $M_{i} \geq 0$, it costs $k\left(M_{i}\right)$, where $k(0)=0, k^{\prime}>0$, and $k^{\prime \prime}>0$. A regime's state capacity is strongest at its center of deployment, $G_{i}$; for a location that is $t$ distance away from $G_{i}$, regime $i$ 's state capacity on that location is $m\left(M_{i}, t\right)=\max \left\{M_{i}-\mu(t), 0\right\}$, where $\mu(0)=0$, $\mu^{\prime}>0$, and $\mu^{\prime \prime}>0$.

When $S=2$, instead of assuming exogenous border formation, we now allow regimes $l$ and $r$ to compete for land. Let regime $l$ controls $[0, b]$ and regime $r$ controls $[b, 1]$, where $0 \leq b \leq 1$. The border $b$ is the location between $G_{l}$ and $G_{r}$ at which the two regimes are evenly matched in state capacity. Specifically, $b$ is defined by:

$$
m\left(M_{l}, b-G_{l}\right)=m\left(M_{r}, G_{r}-b\right)
$$

State capacity not only helps to define the border, it also acts as a deterring force to block the external threat from spreading inland. Consider a threat emanating from $x=0$, a location $x \in[0, \chi]$ is protected by regime $i$ from the external threat originating from 0 if there exists $0 \leq \hat{x} \leq x$ such that $\lambda(\Lambda, \hat{x})-m\left(M_{i}, G_{i}-\hat{x}\right) \leq 0$. In a symmetric fashion, a location $x \in[0, \chi]$ is protected by regime $i$ from the external threat originating from $\chi$ if there exists $x \leq \hat{x} \leq \chi$ 
such that $\lambda(\Lambda, \chi-\hat{x})-m\left(M_{i}, \hat{x}-G_{i}\right) \leq 0$.

If a contiguous segment of length more than $\delta$ (where $0<\delta<1$ ) is left unprotected, then a revolution occurs and the authority (or authorities if there is more than one) that taxes the segment collapses. If the revolution constraint is not violated, the net revenue of regime $e$ under empire is $V_{c}=\chi y-k\left(M_{c}\right)$ while the net revenues of regimes $l$ and $r$ under interstate competition are $V_{l}=b \chi y-k\left(M_{l}\right)$ and $V_{r}=(1-b) \chi y-k\left(M_{r}\right)$, respectively.

The optimization problem facing a centralized state (Authority $c$ ) is straightforward: it first decides $G_{c} \in[0,1]$ and then $M_{c} \geq 0$ to maximize its net revenue $V_{c}=\chi y-k\left(M_{c}\right)$. Since this is a two-stage decision process, we employ backward induction to solve the model.

Under political decentralization $(S=2)$, authorities $l$ and $r$ simultaneously choose $G_{l}$ and $G_{r}$. After observing the locations, they then simultaneously make investments $M_{l} \geq 0$ and $M_{r} \geq 0$. Again, we employ backward induction to solve the model.

Let $\bar{\Lambda}$ be defined by $\lambda(\bar{\Lambda}, \delta)=0$. Below, we restate Propositions $1-4$ of Section 3 .

Proposition 1 (Centralization, One-Sided Threat). When the threat is one-sided and emanates from $x=0$ :

A. If $\Lambda_{l} \leq \bar{\Lambda}$, the centralized state locates the base at $G_{c} \in\left[\frac{\Lambda_{l}}{\alpha}, \chi\right]$ and makes zero investment in state capacity;

B. If $\Lambda_{l}>\bar{\Lambda}$, the centralized state locates the base at $G_{c}=\delta$ and invests to the level $M_{c}=\lambda\left(\Lambda_{l}, \delta\right)$.

Proposition 2 (Centralization, Two-Sided Threats). Under threats from both $x=0$ and $x=\chi$ :

A. If $\Lambda_{l}=\Lambda_{r} \leq \bar{\Lambda}$, the centralized state locates the base at $G_{c} \in\left[\frac{\Lambda_{l}}{\alpha}, \chi-\frac{\Lambda_{r}}{\alpha}\right]$ and makes zero investment in state capacity;

B. If $\Lambda_{l}=\Lambda_{r}>\bar{\Lambda}$, the centralized state locates the base at $G_{c}=\frac{\chi}{2}$ and it invests to the level $M_{c}=\lambda\left(\Lambda_{l}, \delta\right)+\mu\left(\frac{\chi}{2}-\delta\right)$.

Proposition 3 (Decentralization, One-Sided Threat). Under an external threat emanating from $x=0$, there exists $\Lambda^{*}$ such that:

A. If $\Lambda_{l} \leq \bar{\Lambda}$, regime l locates its base at $G_{l} \in\left[\frac{\Lambda_{l}}{\alpha}, \frac{1}{2} \chi\right]$; regime $r$ locates its base at $G_{r}=\chi-G_{l}$; $b=\frac{\chi}{2} ;$ and $M_{l}=M_{r}>0$.

B. If $\Lambda_{l} \leq \Lambda^{*}$, regime l locates its base at $G_{l} \in\left[\frac{\Lambda_{l}}{\alpha}, \frac{1}{2} \chi\right]$; regime $r$ locates its base at $G_{r}=\chi-G_{l}$; $b=\frac{\chi}{2}$; and $M_{l}=M_{r}>0$. 
C. If $\Lambda_{l}>\bar{\Lambda}$ and $\Lambda_{l}>\Lambda^{*}$, regime l locates its base at $G_{l} \in\left[\frac{\Lambda_{l}}{\alpha}, b\right]$; regime $r$ locates its base at $G_{r}<\chi-G_{l} ; b<\frac{\chi}{2} ;$ and $M_{l}>0, M_{r}>0$.

The intuition of this proposition is as follows. If the external threat is small enough so that the revolution constraint never binds $\left(\Lambda_{l} \leq \bar{\Lambda}\right)$, regimes $l$ and $r$ will focus on competing for land with each other (Case A). Importantly, because border formation is now endogenous and the regimes have to invest in state capacity to compete with each other, even if there exists a non-trivial external threat from the left frontier, the state capacity that the left regime built to compete with the right regime is sufficient to block the threat and no additional investment on state capacity is required as long as $\Lambda_{l} \leq \Lambda^{*}$ (Case B). It is only when the threat from the left frontier is sufficiently large $\left(\Lambda_{l}>\bar{\Lambda}\right.$ and $\left.\Lambda_{l}>\Lambda^{*}\right)$ that the left regime has to actively deal with it. In this situation, it will have to shift its base leftward and this will cause it to cede land to the right regime (Case C).

Proposition 4 (Decentralization, Two-Sided Threats). Under threats from both $x=0$ and $x=\chi$, there exists $\Lambda^{*}$ such that:

A. If $\Lambda_{l}=\Lambda_{r} \leq \bar{\Lambda}$, Authority l locates its base at $G_{l} \in\left[\frac{\Lambda_{l}}{\alpha}, \frac{1}{2} \chi\right]$; Authority $r$ locates its base at $G_{r}=\chi-G_{l} ; b=\frac{\chi}{2}$; and $M_{l}=M_{r}=M^{*}>0$.

B. If $\Lambda_{l}=\Lambda_{r} \leq \Lambda^{*}$, Authority l locates its base at $G_{l} \in\left[\frac{\Lambda_{l}}{\alpha}, \frac{1}{2} \chi\right]$; Authority $r$ locates its base at $G_{r}=\chi-G_{l} ; b=\frac{\chi}{2}$; and $M_{l}=M_{r}=M^{*}>0$.

C. If $\Lambda_{l}=\Lambda_{r}>\bar{\Lambda}$ and $\Lambda_{l}=\Lambda_{r}>\Lambda^{*}$, Authority l locates its base at $G_{l} \in\left[\frac{\Lambda_{l}}{\alpha}, \frac{1}{2} \chi\right] ;$ Authority $r$ locates its base at $G_{r}=\chi-G_{l} ; b=\frac{\chi}{2}$; and $M_{l}=M_{r}>M^{*}>0$.

As in Proposition 3, Proposition 4 states that if the external threats are sufficiently small, regimes $l$ and $r$ effectively ignore them and focus on competing with each other (Cases A and B). This is because the state capacity that each regime built to compete with each other is sufficient to deal with the threats and no extra investment is required. But when the threats are large, the regimes will have to respond by increasing their respective investments in state capacity (Case C). 